\title{
How psychoactive drugs shape human culture: a multi-disciplinary perspective
}

\begin{abstract}
Psychoactive drug use occurs in essentially all human societies. A range of disciplines contribute to our understanding of the influence of drugs upon the human world. For example pharmacology and neuroscience analyse biological responses to drugs, sociology examines social influences upon people's decisions to use drugs, and anthropology provides rich accounts of use across a variety of cultural contexts. This article reviews work from multiple disciplines to illustrate that drugs influence aspects of culture from social life to religion, politics to trade, while acting as enablers of cultural change throughout human history. This broad view is valuable at a time when the influence not only of traditional drugs but a growing armoury of novel drugs is felt and debated.
\end{abstract}

\section{Keywords}

drugs; culture;

\section{Corresponding author}

Dr Greg Wadley

The University of Melbourne,

Parkville,

Victoria, 3010,

Australia

phone +61383441586

email: greg.wadley@unimelb.edu.au

accepted on 11th April 2016 for publication in Brain Research Bulletin 


\section{Introduction}

Psychoactive drug use occurs in essentially all human societies (Withington, 2014; Thakker, 2013). The use of mind-altering substances has been central to a range of human phenomena from shamanic rituals to village pubs to youth counter-cultures (Shortall, 2014). This paper argues that drugs are not merely components of, but rather significant influences upon culture.

It is a remarkable thing, easily overlooked because it is so commonplace, that a very small dose of a chemical can change the way someone thinks and feels. Furthermore, this subjective change can be so compelling that a desire to repeatedly experience it motivates individuals and groups to carry out complex plans that play out over timescales ranging from hours to decades. A range of research disciplines contribute to our understanding of the influence of drugs upon the human world. A major focus has been on why people take drugs and what happens to them when they do (Withington, 2014). While effects upon individuals are a focus of biomedical research (Schultes, 1969), disciplines such as anthropology, evolutionary biology and ethics contribute to an understanding of the broader impact of drugs (Guerra-Doce, 2015). Each of these addresses a critical part of what Withington calls "the cumulative importance of intoxication"; yet none can alone address the complete picture.

\subsection{Material and Method}

This article reviews work from multiple disciplines to shed light on the role of drugs in culture and cultural change. Material was drawn from key journals, books and annual reviews in relevant disciplines, as well as secondary sources that take broader cultural or historical views, with the intention of providing a concise but thorough overview of current thought. This broad view is valuable at a time when societies debate the influence not only of traditional drugs but a growing armoury of novel drugs. The sections following review categories by which we understand drugs and culture, the ubiquity and variety of drug use, the ways in which drug use has influenced culture and behaviour, and syntheses of the role of drug use in the larger human story.

\section{Categories and definitions}

\subsection{Psychoactive drugs}

Drugs are substances exogenous to the body which, when ingested, influence biological function by mimicking the action of neurotransmitters upon neurons (Kenakin, 2004). This paper is concerned with psychoactive drugs - those that influence brain functions such as emotion, thought and behaviour.

Sherratt (1995a), introducing the trail-blazing collection of anthropological essays on drugs Consuming Habits (Goodman et al., 1995), argued that when analysing drug use it is important first to clarify terminology, since the language of drugs is morally charged and carries legal, ethical and referential meanings that vary in time and space (see also Withington, $2014 \mathrm{p}$. 14). Biological definitions of the term drug disregard a substance's legal status and the purposes for which it is administered. However, legal status and purpose of use are incorporated into the semantics of informal language. The Oxford English Dictionary lists both a scientific definition 
of "drug" and this vernacular one: "A substance taken for its narcotic or stimulant effects, often illegally." Hugh-Jones (2007) noted that the concept of drug depends on: "a specific set of rules, norms and conventions concerning the appropriate ways in which these substances are to be distributed and consumed." Thus non-medical drug use is often called "abuse", regardless of whether it is problematic, or "recreational" when the purpose for using might well be workrelated (cf. Glantz, 2013).

The distinction between medical and recreational use is ancient and cross-cultural (Courtwright 2001, p. 89); however "medical" drugs are frequently abused, and most illegal "drugs of abuse" have at some time or place been used medically - heroin and cannabis are examples. The concept of $d r u g$ is often tied to the phenomenon of addiction; yet not all illegal drugs are addictive (e.g. lysergic acid diethylamide, LSD), some legal drugs are addictive (e.g. nicotine), and the harm to society from legal drugs outweighs that caused by illegal drugs (Gowing, 2014). History shows that the legality of a drug tends to be somewhat arbitrary and dynamic: Kushner (2010) noted that it depends more upon "social norms and power relationships" than on pharmacological properties. Medical, religious and recreational use has often been intertwined. Thousands of psychoactive plants have been used in traditional medicines in every area of the globe (and significant research is devoted to exploring their potential to yield new drugs). As drugs cross borders, the conceptual boundaries between legal and illegal, drug and medicine can shift, as demonstrated for example in the widespread prescription of antidepressants by unlicensed doctors in India (Ecks and Basu, 2014).

Newly-engineered pharmaceuticals such as those described elsewhere in this special issue can be difficult to categorize within mainstream schemas of legality, addictiveness and purpose of use. Designer drugs emulate the effects of traditional illegal drugs but are made structurally different in order to avoid prosecution. Authors such as DeGrandpre (2006) have highlighted the "confusion and chaos" of our ethical thinking around drugs: as one drug becomes restricted, pharmacologically equivalent, not-yet-illegal drugs are rapidly devised. There is debate about the ethical status of emerging approaches to mental and physical enhancement using novel and existing psychiatric medicines.

Evolution in legal, political and scientific thought, consumer preference, commercial activity, colonialism and globalization have impacted how societies categorize and understand drugs. For this reason Sherratt (1995a) felt that "drug" was too imprecise for academic discourse and preferred the neutral term "psychoactive substance". Terms such as "psychotropic" and "psychopharmaceutical" are evocative and precise, but unwieldy. A recent issue of the Journal of Ethnopharmacology (Lo et al., 2015) discusses the fuzzy boundary between food and drugs, noting that spices, which sit astride this boundary (see Bourgeouis et al., 2014), have inspired global commerce comparable to the drug trade. When drugs are eaten with food, their effects on mood can be confused with nutritional benefits (Hagen et al., 2013). Thus Jankowiak and Bradburd (1996) used the term "drug foods" to refer to alcohol, coffee and chocolate. Courtwright (2001) acknowledged the complex semantics of the word "drug" but chose to use this word for brevity, intending the term to encompass all psychoactive substances whether legal or illegal, natural or artificial, and used for medical or recreational purposes. Using this familiar if loaded word helps to reinforce the common properties that all psychoactive substances possess while undermining artificial boundaries. This paper follows Courtwright in referring to "drugs", and emphasizing that to fully understand the impact of these substances, one ought not to exclude arbitrarily-defined subsets. 


\subsection{Drug use}

In elaborating influences upon culture, one should also define drug use as broadly as possible. In pharmacology, psychology, sociology and some anthropology, the focus of drug research is often on compulsive use or addiction: "putative enslavement to a substance or activity" (Weinberg, 2011). Compulsive use can have devastating consequences for users, family, friends and society if the drug, its vehicle or means of administration have negative effects on health, or the cost of regular administration is so high that the user is forced to adopt illegal, unhealthy or stigmatized methods of making money. Though drug use is an ancient phenomenon, serious addiction is a modern one, becoming widespread with the distillation of spirits, the isolation of active ingredients such as morphine and cocaine, the invention of effective means of administration such as the hypodermic syringe and the cigarette, and the globalization of traditional, regional drug cultures (Westermeyer, 2013). Addiction involves multiple processes operating at different levels of organization, and a large multi-disciplinary body of work debates how the phenomenon should be understood: for example whether it is a disease or conversely whether the disease model diverts too much attention from environmental and social factors (Skewes and Gonzalez, 2013; Garriott and Raikhel, 2015). Discourse on addiction is prominent and shaped by a range of medical, legal, scientific and political actors (Courtwright, 2012). Yet as Muller and Schumann (2011) point out, addiction represents only a small fraction of total drug use. Drugs have played "multiple, often positive social roles-as markers of identity, occasions of conviviality, talismans of faith - that had little to do with addiction" (Courtwright, 2012 p.489). The vast majority of people make routine use of "mundane drugs" (Sullivan and Hagen, 2002) without experiencing major addiction.

With the focus of attention on problematic use by a minority, is it possible we are overlooking interesting effects that accrue from mundane drug use by the majority? Noting that as much as a quarter of the US adult population may be taking psychopharmaceutical medication (Jenkins, 2010), ethicists such as Levy et al. (2014) have asked whether widespread drug use might be influencing moral behaviour in subtle ways, while authors such as Smail (2007) and Courtwright (2001) have explored the socio-political implications of wide-scale drug use; these perspectives are discussed below.

\subsection{Culture}

Which phenomena might be shaped by drugs? Culture is a key concept in several disciplines, and there is debate over what precisely it comprises. Harris (1968) divided culture into levels: infrastructure (how people satisfy biological needs), structure (the domestic and political economy) and superstructure (religious, intellectual and artistic endeavours). Kehoe (2013) refers to a set of patterned behaviour associated with a particular group, and one can speak of "a" culture, defined by the OED as: "the ideas, customs, and social behaviour of a particular people or society". Thus, culture varies in time and space and can refer to material artefacts, learned individual and social behaviours, customs, rituals and religion, artistic practices, economic behaviour and socio-political structures.

Humans transmit culture down the generations via social learning. The analogy with genetic transmission has led to theories of gene-culture co-evolution (Richerson et al., 2010). Kitayama and Uskul (2011) speak of culture as being "embrained", meaning that it is reflected in neural patterns, requires brains for existence and transmission, and is constrained by biology and psychology. Lende and Downey (2012) speak of the "encultured brain" and propose a unification of anthropology, psychology and neuroscience to explore interactions between brain and culture. 
Since culture reflects beliefs, desires, emotions and behaviours, to the extent that drugs influence these subjective experiences they should influence their expression as culture. The next two sections marshal evidence for this model by surveying the range of drugs in use and the mechanisms by which they influence behaviour and culture.

\section{Variety and ubiquity of drug use}

The majority of contemporary humans regularly use drugs (Anderson, 2006; Kennedy, 2014), and drug use figures prominently in all known cultures going back to antiquity (Sherrat, 1995a; Withington, 2014). Quantum increases in variety and usage occurred with the adoption of farming (Crocq, 2007; Wadley and Hayden, 2015), the colonization of the New World and industrialization (Goodman, 1995; Courtwright, 2001), and with the development of drug synthesis techniques (Courtwright, 2001; Levy et al., 2014).

Drugs were used in pre-agricultural, foraging societies (Saniotis, 2010:481; Thomas, 2003) though primarily in medicine (Guthrie and Ho-Yen, 2011) and ritual (VanPool, 2009). Many traditional plant extracts induce hallucinations or trance states and have been central to the practice of religion in forager societies. Hallucinogens such as N,N-dimethyltryptamine (DMT), psilocin and mescalin allow shamans to enter trance states (Merlin, 2003, p. 295; VanPool, 2009) and were used from thousands of years ago in Central Asia, Central America and the south-western United States (Crocq, 2007). The powerful effects of hallucinogens deter widespread consumption, so that use among foragers is restricted to religious specialists. Plantderived stimulants and sedatives such as caffeine and khat (Africa), cocaine (South America), kava and betel (Asia-Pacific) and nicotine (America and Australia) have been used by traditional societies during social interaction, to increase productivity and to relieve boredom, fatigue and hunger. Foraging peoples have provided to hunting dogs stimulants to improve their attention and work rate, and hallucinogens, though it is uncertain whether the latter represents magical practice or improves the dog's ability to detect prey via heightened senses (Bennett, 2015). Thousands of plant species have been used in traditional medicines in every area of the globe. A large research effort, such as that published in the Journal of Ethnopharmacology, is devoted to identifying traditional herbal drugs, testing their effects in the laboratory, and exploring their potential for modern medicine. Many traditional remedies are psychoactive, used for example to relieve pain or melancholy, such as the opioid-like kratom leaf discussed elsewhere in this issue.

With the adoption of farming, the focus of production and consumption shifted from perception-altering to mood-altering drugs (Merlin, 2003; Smail, 2007). Farming enabled larger quantities of drugs to be reliably produced and regularly consumed (Saniotis, 2010; Sullivan and Hagen, 2002). Old drugs were domesticated and cultivated (e.g. tobacco) and new ones were invented (e.g. beer and wine). Archaeobotanical evidence for psychoactive plant use increases significantly with the Neolithic transition (Guerra-Doca, 2015). Early Asian farmers produced alcohol, while Americans produced alcohol, coca, tobacco, and cacao. In the areas to which farming spread, Europeans added opium and cannabis to the crop complex received from the Near East, while in India farmers grew grains for alcohol, and in Africa coffee and kola became major trade items (see table 1 in Wadley and Hayden, 2015).

Most of the drugs domesticated by Neolithic farmers are still in widespread use. The past half-millennium has seen the globalization and purification of traditional drugs (e.g. cocaine, morphine, alcoholic spirits) and the invention of new ones (e.g. amphetamines, psychiatric medicines) along with massive increases in scales of production and distribution (Courtwright, 2001). The remainder of this section surveys the range of drugs in common use. 


\subsection{The "big three": alcohol, nicotine and caffeine}

Alcohol, nicotine and caffeine - Courtwright's (2001) "big three" - have enjoyed widespread use as well as social and legal approval in so many cultures (Crocq, 2007) that they are more-or-less immune to prohibition, with alcohol often obtainable even where religion forbids it (Courtwright, 2001). Yet legal drugs create significant public health concerns, with a recent report showing a quarter-billion people worldwide with alcohol use disorders and a billion smoking tobacco (Gowing, 2014).

Alcohol may have been ingested by early humans eating fermented fruit, a behaviour that may have evolved in primates (Dudley, 2002). However alcohol was probably not used in appreciable amounts prior to farming. Alcohol production is a hallmark of Neolithic transitions around the world: first appearing from 12,000 years ago among cereal farmers in the Middle East (Hayden et al., 2012), China (McGovern et al., 2004), Central America (Smalley and Blake, 2003), Incan South America (Staller, 2009), and India (Fuller, 2005). Alcohol cannot be obtained by simple extraction but is the product of a complex technological and biochemical process (Hayden et al., 2012) requiring significant organization and a sophisticated material culture. Part of the impact of alcohol on culture is therefore tangible in the form of brewing, consumption and storage equipment, such as the vast quantities of amphorae discovered in Bronze Age and especially Mediterranean maritime archaeology. While most early alcohol was probably brewed in beer, wine from grapes and other fruit was a staple by the time of the GrecoRoman civilization (Sherratt, 1995b). Plants other than cereals and grapes have been fermented: for example African societies used cereals, honey, plantain and palm trees (Nugent, 2014), while Soukand et al. (2015) describe over a hundred species fermented in Eastern Europe, including products comprising both food and drugs such as a traditional Estonian gruel prepared from rye, potatoes, milk, poppy and cannabis.

Alcohol has had an enormous impact on social and religious practices around the world (Sherratt, 1995b). Guerra-Doca (2015) discusses its use in rituals and feasts in prehistoric Eurasia. It played a major role in public and private life in most of the major early civilizations, where it was consumed at religious, political and social events (Jennings et al., 2005). Public alcohol consumption helps reinforce social relations and political power (Guerra-Doca, 2015; Dietler, 1990; Hayden, 2014). It is so deeply embedded in modern Western culture that it has survived the "challenges of other, more stimulating drinks acquired through the colonial experience" (Sherratt, 1995a) as well as attempts to prohibit its use. In a great many societies alcohol has served to enhance solidarity and social life (see below), recognition of which has placed anthropologists at odds with medical researchers who are more likely to focus on illeffects (Singer, 2012).

Nicotine is an alkaloid found naturally in tobacco plants (genus Nicotiana) and a few other species. It is habit-forming (Pontieri et al., 1996) and has multiple effects including relaxation, stimulation and pain relief (depending on dose), enhanced memory and concentration, reduction of anxiety, and psychological reward. Tobacco has been used by American and Australian foragers and was domesticated in tropical America as early as 4,000 years ago (Rafferty, 2006) where it was used in rituals, as medicine, and for trade and recreation (Wilbert, 1979). While tobacco was probably originally used by shamans, with cultivation its use became more democratized (von Gernet, 1995). Tobacco spread throughout the Americas and was probably introduced into North America along with maize by at least two thousand years ago (Rafferty, 2006). Pituri, a source of nicotine native to Australia, was a major trade good in pre-colonial Australia (Silcock et al., 2012).

After the discovery by Europeans of the New World in the $15^{\text {th }}$ century, tobacco became a major driver of Atlantic colonization and trade (Price, 1995). In response to increasing 
popularity, attempts were made in the $16^{\text {th }}$ century to grow tobacco in Europe. Tobacco was the economic lifeline of the English colony of Virginia, inspiring other European countries to found tobacco colonies. European traders sold it to native fur trappers in North America; thus tobacco became an integral part of trans-Atlantic commerce (Van Geret, 1995). Along with other New World drugs, the use of tobacco skyrocketed in Europe, helping to create a new kind of economy based on mass consumerism (Goodman, 1995). Its enormous popularity in the $17^{\text {th }}$ century allowed European governments to increase their tax take, so that governments became financially reliant on mass drug use. Debates took place in Europe over whether tobacco should be grown at home or in the colonies, and how it should be taxed in order to maximize revenue (Price, 1995). When introduced to Islamic regions there was debate over whether tobacco (along with coffee) was compatible with religious teaching (Matthee, 2014). Though nicotine consumption is associated with addiction and disease, research indicates that tobacco use protects against parasite infestation in central Africa (Roulette et al., 2014) and that individual users modulate intake in response to infestation, demonstrating the possibility that drug use can be adaptive (Sullivan and Hagen, 2002).

Caffeine is a psychoactive alkaloid obtained from the coffee, tea, cocoa, kola and guarana plants and is currently the world's most popular drug. More than $85 \%$ of Americans make significant use of it (Weinberg, 2000). It is a stimulant, can reduce anxiety and depression (Pechlivanova et al., 2012), and may be an effective treatment for attention deficit hyperactivity disorder (ADHD) (Ioannidis, 2014). Caffeine enhances performance on several cognitive tasks - though in some cases only for extroverts (Smith, 2013).

Caffeine-yielding plants are native to a number of regions. Coffee was first exploited in Ethiopia 1500 years ago (Anthony et al., 2002) while tea was used in China at least 2,000 years ago (Chen, 2005). Fermented cacao (which also contains the pharmacologically similar alkaloid theobromine) was in use over 2000 years ago in central America (Powis et al., 2002) and may have enabled Olmec societies to expand trade and power in Mesoamerica. Subsequently chocolate was used in social and ritual settings by the Mayans and served as a currency and elite drink for the Aztecs. A major source of caffeine in Africa is the kola nut, which has been cultivated and traded around Sudan for 1,000 years (Lovejoy, 1995). With the Islamic proscription of alcohol, kola became a prestige good and a component of various cultural practices. It was given to dinner guests, used for official gifts, and distributed by would-be "big men" to curry political favour. It was used as a courtship gift and believed to induce sexual desire in women; given to labourers as compensation and to combat fatigue, and to soldiers to increase bravery before battle (Lovejoy, 1995). Kola became the basis of European and American tonic drinks, though most manufacturers now source their caffeine elsewhere.

The introduction of caffeine to eighteenth century Europe impacted material culture and domestic and public space (Smith, 1995). Caffeinated drinks replaced the traditional breakfast of porridge and alcohol (Goodman, 1995) and helped shift the focus of public life to cafés, with a concomitant increase in political activity (Smith, 1995). Coffee houses provided a forum to discuss politics and art and helped to spread ideas across class boundaries (Courtwright 2001, p. 101). Chocolate grew in popularity in $18^{\text {th }}$ century Europe and became deeply embedded in European culture (Goodman, 1995).

\subsection{Drugs that currently are widely proscribed}

Cannabis is probably native to central Asia (Clarke and Merlin, 2013). It was one of the earliest drugs used in China and India (Merlin, 2003) and is mentioned in ancient Indian texts. It spread via the Eurasian steppes to Eastern Europe soon after initial domestication (Rudgley, 1995). The primary psychoactive alkaloid is tetrahydrocannabinol (THC), but cannabis also 
yields food (from oils and starches in the seeds) and hemp (from the stems) used in textiles and paper (Clarke and Merlin, 2013). Cannabis creates euphoria, reduces anxiety and pain and is mildly hallucinogenic (Ashton, 2001). It has featured in religions throughout Europe and Asia including Hindu, Scythian, Zoroastrian and Chinese shaman cultures from over 2000 years ago (Clarke and Merlin, 2013). Cannabis was a major crop in the $19^{\text {th }}$ century British empire (Mills, 1995), where Indian labourers smoked cannabis at work, with visitors at home, and at religious and cultural ceremonies. Imperial labourers took cannabis to South Africa and probably the West Indies (Mills, 1995). Cannabis was banned but did not disappear after the Muslim conquest of Egypt in the $14^{\text {th }}$ century; a later ban by the British led to the creation of an international smuggling route which persists today (Mills, 1995).

Cocaine derives from the coca plant, domesticated in the Andes where it was used for millennia to mask fatigue, hunger and pain (Plowman, 1984) and where millions still use it daily (Burchard et al., 1992). There is evidence of coca use as early as 8,000 years ago in northern Peru, where it "was a feature of the rise of agriculture and social complexity in the region" (Dillehay et al., 2010). Coca was a status marker for Incans and was accorded religious significance (Plowman, 1984). After the active ingredient cocaine was isolated it became a popular stimulant and local anaesthetic in Europe and the United States, and was mixed with wine and kola to create popular tonic drinks. Courtwright (1995) describes cocaine epidemics in the late $19^{\text {th }}$ and late $20^{\text {th }}$ century USA. It was used by $19^{\text {th }}$ century labourers until perceptions of its addictive potential and ability to engender crime and incivility caused its popularity to decline, until it was eventually banned. Its popularity revived in the 1980s, as new trading routes and forms of administration were pioneered (Courtwright, 1995).

Amphetamines are synthetic drugs that, like cocaine, stimulate dopamine release to create a feeling of energy. They are used under prescription to treat attention deficit disorder and without prescription to enhance wakefulness, mental and physical performance, and sociability. Originally sold as cold medicine in the early $20^{\text {th }}$ century, amphetamines were soon used by students and military personnel and then prescribed widely for a range of psychological conditions, before their addiction potential saw them progressively restricted from the 1970s on (Courtwright, 2001 p. 81). Shift workers, truck drivers and soldiers take amphetamines for alertness and improved work output, while up to a third of university students take them to improve study performance (Petersen, 2015). Amphetamines have high addiction potential and sustained use can induce psychosis (Fulde and Forster, 2015).

Plant-based hallucinogens such as psilocybin, mescaline and DMT have been employed for spiritual and ceremonial purposes in forager societies (VanPool, 2009). Artificial hallucinogens such as LSD were synthesized in the mid- $20^{\text {th }}$ century. They were initially used in psychological research and treatment, but after promotion by public figures such as Aldous Huxley and Timothy Leary, became an iconic drug of choice for youth subcultures (who were partly inspired by Native American use of psilocybin), after which they became illegal in most countries. There were political aspects to the countercultural adoption of LSD, with some viewing it as a revolutionary tool, and charismatic leaders controlling followers via their drug supply (Shortall, 2014).Subjective experiences include hallucinations, euphoria and intense spiritual or religious feelings, leading to some naming these drugs "entheogens", however if the user's mindset and context are inappropriate such experiences can transform into anxiety and psychotic-like episodes (Griffiths et al., 2006). Currently there is renewed interest in hallucinogens as a treatment for anxiety and depression (Majic et al., 2015; Hendricks, 2015) and palliative care (Grob et al., 2013).

Opiates are derived from the opium poppy, which is native to Mediterranean Europe and was probably the first plant added to the Neolithic crop complex imported from the Levant (Zapata, 2004; Guerra-Doce, 2015). Poppies, cereals, and pulses formed the plant assemblages 
of the first farmers in Italy (Merlin, 2003), and opioids have been found in the bones of Neolithic miners and at burial sites in Spain (Zapata, 2004). Opium became widely used around the world medicinally and recreationally (Levinthal, 1988), especially in the Islamic world where it was an alternative to alcohol (Matthee, 2014) and in China and diaspora countries including the United States (Courtwright, 2001). The active ingredient morphine was isolated in the early $19^{\text {th }}$ century, and the variant diamorphine (heroin) synthesized in the late $19^{\text {th }}$ century; both substances enjoyed success as commercial medicines until their addictive power was recognized and legal proscription began in the $20^{\text {th }}$ century. Opiates have been associated with subcultures and avant-garde artists and have inspired significant literature, film and music (see e.g. Hussey, 2013). They have been prescribed for almost every medical condition. The use of legal prescription opiates is burgeoning in Western cultures due to increased incidence of chronic pain and palliative care as well as illicit use, all of which can lead to term long-term dependence (Berterame et al., 2016).

\subsection{Drugs traditionally used outside the Western context}

While several drugs discovered during European colonialism were successfully exported back to Europe, many other regionally popular drugs have not been globally adopted, mainly due to aesthetic and logistical problems such as short shelf-life (Courtwright, 2001). At the same time, a number of traditional herbal drugs, once widely used in Europe, lost their currency with the rising popularity of New World drugs.

Betel is a stimulant produced from the nut of the areca palm, the leaf of the betel pepper, and lime (Norton, 1998). Betel chewing was well established in China and India 2000 years ago (Norton, 1998) and forms part of daily life for 200 million people in coastal areas of the Western Pacific and South Asia. Globally only nicotine, alcohol and caffeine are more widely used (Norton, 1998). The betel nut features in origin myths and has cosmological significance, and is very important to the economy of Papua New Guinea (Hirsch, 1995). It is used to enhance work and social activities, and given symbolically to guests and at important occasions such as marriages and funerals.

Khat is a stimulant/relaxant used traditionally in the horn of Africa and Yemen, and now popular in neighbouring countries and among the African diaspora in Europe and North America. Traditional khat use is highly routinized, part of daily work routines and social gatherings, negotiations, marriages and funerals, and religious ceremonies (Klein and Beckerleg, 1995). Before air travel it was difficult to transport khat over long distances because the leaves degrade quickly, but khat is now used in diaspora cultures in Europe (Bongard and Nakajima, 2015), leading to concerns about abuse (Odenwald et al., 2010).

Kratom has opioid-like properties and has been chewed, smoked and drunk in SouthEast Asia for thousands of years to enhance energy and mood, dull pain, to remedy various medical problems including opiate addiction, to enhance sexual performance, and to prevent exhaustion and hunger in workers (Hassan et al., 2013). It has recently become available for purchase over the Internet and is becoming a popular drug globally, inspiring research into its potential for good or harm (Stolt et al., 2014 and papers in this special issue).

\subsection{Sugar and food addiction}

Humans eat sweet, energy-dense foods in response to depression, stress and negative affect (Gibson, 2012). "Comfort foods" (Dube et al., 2005) induce "a psychologically comfortable and pleasurable state" (Wansink et al., 2003) and may lead to food addiction (Ifland et al., 2009; Davis et al., 2014; Volkow and Wise, 2005). Sucrose has come to be seen as having 
drug-like properties: it acts as an analgesic (Blass et al., 1987), reduces stress (Ulrich-Lai et al., 2010) and future-discounting (Wang and Dvorak, 2010), and repeated consumption leads to tolerance and withdrawal (Johnson and Kenny, 2010). High-fructose corn syrup is added to many foods and may be more hedonic and addictive than sucrose (Leri and Levy, 2015). Compulsive eating is associated with obesity, depression and hyperactivity (Davis et al., 2011) and supports a global industry that satiates the craving (Volkow and Wise, 2005).

Humans are drawn to sweet tastes probably because in ancestral environments they signalled high nutritional value (Lenoir et al., 2007). Preference for sweetness has driven a desire for sucrose-yielding plants since ancient times. Sugar cane appears to have been first used at least 6,000 years ago in New Guinea (Daniels and Daniels, 1993; Bellwood, 2011). Its cultivation and use spread throughout Asia and the Islamic world into Europe and thence via colonization to tropical Africa and America (Grivet et al., 2004). With the development of crystallization and large-scale plantations, sugar become widely available to non-elites. During the $19^{\text {th }}$ century British working class people began using it to sweeten tea, coffee and chocolate: imported drugs whose use was also rapidly democratizing (Courtwright, 2001). Demand became so great that sugar, like tobacco, was a major driver of colonization and trade.

\subsection{Medicines and designer drugs}

Plant-derived drugs have been used for millennia to counter aversive mental states. Recently a range of new drugs including antipsychotics, antidepressants, anxiolytics, sedatives, stimulants and painkillers have been synthesized for the treatment of mental health conditions. Many of these are also (ab)used outside of a prescription framework (Petersen, 2015) for purposes that blur the boundary between medicine and enhancement (Pieters and Snelders, 2009). Psychiatric drugs share with drugs of abuse the ability to induce desirable mental states, and can influence behavioural phenomena as varied as motivation, emotion, social functioning, romantic love (Kirmayer and Raikhel, 2009), agency, the sense of being in or under control, and the perceived value of others (Jenkins, 2010). The ability to manipulate molecular structures, along with ubiquitous e-commerce, has given rise to industries that produce new drugs with desirable psychoactive properties, variants on traditional drugs with improved properties, and analogues of traditional drugs designed to evade legal restrictions. These industries continuously augment a "tool kit" (Muller and Schumann, 2011) that affords users ever finer control over their mental states (Farah et al., 2004).

Popular designer drugs include the dissociatives methoxetamine and ketamine, stimulants alpha-pyrrolidinopentiophenone (alpha-PVP, "flakka", "gravel") and methylenedioxypyrovalerone (MDVP, "bath salts"), and the empathogen 3,4-methylenedioxymethamphetamine (MDMA, "ecstasy"). MDMA increases sociability, face-trustworthiness, cooperative behaviour (Stewart et al., 2014), financial generosity (Kirkpatrick, 2015) and the use of social and sexual words (Baggott, 2015), while making identification of social threat less accurate (Bedi et al., 2010). Party drugs are the basis of a global youth culture which sees groups gather to dance and take drugs (Joe-Laidler et al., 2014).

Novel cognitive enhancers improve psychological functions such as memory, attention and work output (as do traditional drugs - see Kirmayer and Raikhel, 2009). Synthetic stimulants such as methylphenidate ("Ritalin") and amphetamine (e.g. "Adderall") are prescribed for attention deficit but also used illicitly by athletes for better performance and by university students to make study more effective and enjoyable (Petersen, 2015). Enhancement is distinct from medicine in that the intention is not to fix a deficit but to enhance normal functioning. Ethicists have begun to address the prospect of moral enhancement by new drugs 
(e.g. Ilieva, 2015 and see below), while anthropologists ask whether what it means to be human is being transformed by designer drugs (Jenkins, 2010).

\section{Mechanisms of influence on culture}

The previous section demonstrated the ubiquity, range, and deep history of psychoactive drug use in human cultures. A broad range of ethnographic and archaeological writing (e.g. in Goodman et al., 1995) has demonstrated that drugs are integral components of culture; fundamental to religion and social life and the formation of cultural identities, civilizations, and the world economy. Withington (2014) lists three primary influences of drugs on culture: the association of intoxication with cultural production, the prominence of drugs in popular discourse, and the economic importance of drug taxation. This section reviews evidence for the influence of drugs on behavioural, material and structural aspects of culture.

\subsection{Motivation to engage in production and consumption}

Many psychoactive drugs are intrinsically rewarding, inducing desirable states such as euphoria (Nesse and Berridge, 1997) and sociability (Velea and Hautefeuilee, 2007), attenuating unwanted states like stress, fatigue and low mood (Morgan et al., 2013; Pickard, 2012), or enhancing mental and physical functioning (Muller and Schumann, 2011; Kirmayer and Raikhel, 2009). These perceived benefits create a powerful motivation to engage in the production and consumption of drugs; activities which for millennia have represented a significant portion of economic and cultural activity.

Drugs with the potential for abuse, such as many of those described in the previous section, directly activate brain pathways that regulate appetitive anticipation and consummatory hedonia (Berridge and Robinson, 1998; Blum et al., 2012). This can induce cravings for repeated use (Robinson and Berridge, 1993) and lead to tolerance and addiction (Koob and Le Moal, 2001). Their salience is perhaps most visible in drug subcultures (Brake, 1980) which form when people share understandings and practices around drug-taking and drug procurement, or a need for security, self-respect and profit (Singer, 2012; Karandinos et al., 2014). Drug subcultures occur in populations as varied as addicts, party-goers, hippies, artists, and criminal gangs (Moore, 2004; Brake, 1980). Outlaw subcultures can incorporate status hierarchies that are "brutally enforced" (Muehlmann, 2013) with weapons and personnel funded by drug commerce. Drug dealers can become defacto leaders and protectors of their community (Karandinos et al., 2014). Karandinos explains this political phenomenon in terms of Marx's "primitive accumulation" theory of the origins of class distinctions. But controlling the supply of a widely-desired drug does not confer power only in outlaw subcultures; rather it has been a prized privilege of governments, military leaders and colonists throughout history. Thus the distinction between subculture and mainstream, like the distinction between addiction and mundane use, is blurred.

Different disciplines understand compulsive drug use by focussing on phenomena that emerge at different levels of organisation. Pharmacologists have built physiological models of addiction involving, for example, dysregulation of a common reward centre (Korpi et al., 2015) and impairment of brain plasticity (Kasanetz et al., 2010). Such models hold out the promise of a pharmacotherapy for addiction (Koob and Mason, 2016) but are challenged by the fact that not everyone exposed to drugs becomes addicted (Volkow et al., 2012). Critics have debated the value of brain disease models and emphasized the complex biosocial (Nutt et al., 2015) and political (Courtwright, 2010) causes of addiction. Sociologists argue that individuals are driven to drugs by social problems such as poverty and inequality (Weinberg, 2011). Anthropologists 
compare drug use across cultures and times and write rich accounts of addiction in specific social contexts (Singer, 2012).

\subsection{Drugs as tools}

While addiction to illicit drugs is a serious social problem that devastates lives, it nonetheless represents only a small fraction of drug use, since most contemporary humans use drugs regularly. Yet the impact of mundane drug use has not received much attention, partly because much of it is not acutely harmful to health. How should we conceptualize mundane drug use, and what is its impact on individuals, societies and culture?

Muller and Schumann (2011) propose a neurobiological framework in which people are seen to instrumentalize drugs, using them as tools to manipulate mental states in order to achieve particular goals. According to this framework, individuals learn the properties of the drugs in their environment, and what can be achieved with them in particular circumstances. Individuals thereby develop a "toolkit" of drugs, which for many will consist of the mainstream, socially-approved drugs of their culture, in particular the "big three" - caffeine, alcohol and nicotine - and commonly-used pharmaceuticals. This framework does not begin by assuming that drug use is a problem, but rather assumes that people use drugs to achieve goals that are important to them. The implication is that researchers should identity the drugs and goals in question, and investigate how people develop the toolkit and achieve goals with it.

The drug instrumentalization framework is based on several pieces of empirical and theoretical work. The possibility that drug use has an adaptive benefit (enhances survival and reproduction) has been proposed by Lende and Smith (2002) who suggested that drug reward acts as a substitute when natural reward cannot be achieved, by Lende et al. (2007) who found that people used illicit amphetamines primarily to enhance productivity, and by Hagen et al. (2013) who demonstrated that some drug use represents a defence against parasites (see also Roulette et al., 2014). Other research has reported users seeking benefits related to mental health, stress reduction, cognitive function, productivity and sociability (references in Muller and Schumann, 2011, p. 295). On this basis it is likely that people are able to detect the affordances of particular drugs and make rational decisions to use them when it would benefit. This implies a cost-benefit calculation which may take into consideration financial, health, legal and social factors. Muller and Schumann propose that a principal problem that drugs solve is the need to rapidly adjust to micro-environments, such as workplaces and social settings, in which individuals are under pressure to hold a particular mindset regardless of their current circumstances. Being able to control one's emotions, cognitive functioning and fatigue level can be essential to success in many social settings. Thus individuals learn to use caffeine, alcohol, nicotine and/or other drugs to attain the state of mind required in a given situation. Psychiatric medicines and cognitive and physiological enhancers fit easily in this framework.

Instrumentalized use of drugs can impact culture in several ways. In competitive social settings such as workplaces, sporting fields and nightclubs, we should expect that the steadilyincreasing availability and variety of drugs would over time create a competitive "arms race" of increasing behavioural adaptations: such as ever-increasing focus and productivity at work, euphoria and sociability at social gatherings, and enhancement of physical and mental abilities. Competition would motivate people to push the boundary between instrumental and harmful use, with some crossing into addiction, and this would lead to regulatory attention being focused on particularly addictive drugs and on those believed to proffer an unfair advantage. Competition would create a constant demand for new, improved drugs to meet life challenges. Drug use would become steadily more universal and globalized as more people felt they must 
adopt these tools. Evidence for this view can be seen in the historical record, in which new drugs are constantly discovered and invented and spread through commerce and colonization.

Other research supports the drug instrumentalization framework. Oldani et al. (2014) describe drugs as a set of tools for modifying or enhancing mood, emotional states, behaviour and social relations. Studies of the use of prescription stimulants such as Adderall (e.g. Petersen et al., 2015) show that students take drugs in order to achieve better grades and enjoy academic work. Farah et al. (2004) noted that alteration of brain function can be used to enhance normal individuals as well as to treat mental dysfunction in those who are ill. Glannon (2006) noted that some medicines erase unhelpful memories and enhance useful ones. Wiegel (2015) found that teachers use drugs for cognitive enhancement and reduction of work-related stress. Kirmayer and Raikhel (2009) in a special issue of Transcultural Psychiatry showed how psychoactive medications are increasingly used to enhance performance, personality and self-presentation, emphasizing that this is a contemporary manifestation of a long (pre)historical trend to seek transformation through drugs.

\subsection{Pro-sociality and moral behaviour}

It would be a rare social gathering that did not involve the consumption of caffeine, alcohol, tobacco, comfort foods or other psychoactive substances; the choice depending on culture and context (Sherratt, 1995a; Hayden, 2014). Anthropologists have described the apparently universal centrality of drug use in social life. In the collections edited by Goodman et al. (1995) and Withington and McShane (2014), Hugh-Jones, Von Gernet, Hirsch and Lovejoy (all 1995) detail the key social roles of drugs in the Amazon, pre-colonial North America, Papua New Guinea and Sudan respectively, while Richards, Osborne, Nugent and Hsu (all 2014) demonstrate similar roles in renaissance England, ancient Greece, contemporary Africa, and colonial Taiwan. Heath (1958) found that consuming high doses of alcohol, to the point of unconsciousness, contributed to Camba social solidarity and created bonds even between introverted people (discussed by Singer, 2012). Joe-Laidler et al. (2014) found that ecstasy helped clubbers "open up, trust others, and achieve emotional connections that are difficult or impossible otherwise". Stromberg (2012), studying smoking among college students, argued that drugs interact with the loss of agency experienced in social gatherings to create a Durkheimian "collective effervescence".

It is likely that the association between socializing and drugs is built upon their pharmacological properties. Many drugs influence an individual's perceptions of and interactions with other people. Pro-social behaviour is facilitated through mechanisms such as reduction of anxiety, enhancement of self-confidence, suppression of fatigue, and disinhibition of communication (Muller and Schumann, 2011:298). Nicotine (Todd, 2004), alcohol (Cooper et al., 2002), and other drugs (Sinha, 2001) reduce social stress, while alcohol enhances mood and reduces symptoms of depression (Muller and Schumann, 2011). Empathogens such as ecstasy increase sociability and make identification of social threat less accurate (Bedi et al., 2010). Stimulants improve theory of mind and empathy in children with ADHD (Maoz et al. 2014). Enjoyment of social interaction is enhanced by exogenous opioids (Trezza et al., 2011), while alcohol is used to remedy an inability to interact socially (Martinotti et al., 2009). Withington (2014) argued that drugs make "loss of cognitive and bodily control" ubiquitous in socializing.

An important aspect of drug-modulated sociality is the ability for some drugs to reduce the subjective stress of living in groups (Velea and Hautefeuille, 2007). People and animals suffer crowding stress (Armario et al., 2008; Brown and Grunberg, 1995; Calhoun, 1973; Epstein, 1981) which is mediated by serotonin (Daniels et al. 2000) and relieved by a range of 
drugs including anti-depressants (e.g., Naitoh et al., 1992), alcohol (Nagaraja and Jeganathan, 2003), opiates (Xigeng et al., 2004) and high-caloric food (Coccurello et al., 2009). In rats, crowded conditions lead to intense competition to establish a status hierarchy, and to anxiety and depression in individuals who suffer social defeat (Leedy et al., 2015). A marked feature of the human story has been population growth and an increase in the proportion of people who live in cities (United Nations, 2012). Ancient and novel drugs may have supported this trend by enhancing prosocial behaviour and alleviating crowding stress (Wadley and Hayden, 2015).

Not only recreational but prescription drugs can increase prosociality. Humans are a social species and have evolved proclivities to behave in ways that benefit others: these are governed by psychological mechanisms that help ensure that the benefit-giver (or their kin) is not disadvantaged (Kurzban et al., 2015). These psychological mechanisms of ethical judgement can be pharmacologically manipulated. Antidepressants that target serotonin receptors reduce hostility and increase warmth and gregariousness (Ilieva, 2015). Pieters and Snelders (2009) argue that the line between healing mental illness and enhancing the normal mind is fine and frequently crossed, with consumers taking pharmaceuticals to "make them feel better about living in a modern world." A number of existing, commonly-prescribed pharmaceuticals modify moral judgements and behaviour, in particular propranolol and drugs that target serotonin or oxytocin (Levy et al., 2014). Users of these drugs are more likely to forget traumatic events, are less risk-averse, more cooperative and less critical, will distribute money more fairly, and are easier to exploit and more trusting (even after betrayal), though only to in-group members. People's willingness to harm others can be manipulated by administration of serotonin reuptake inhibitors and dopaminergs (Crockett at al., 2015). Levy et al. point out that for drugs that are used widely, even small ethical reorientations in individuals can aggregate to have a significant impact on how a large group functions. Ethicists are debating whether "moral enhancement" through drugs ought to be implemented, since while society might benefit from reduced immoral behaviour and increased public safety, this occurs at the expense of the individual whose morality is corrected (Focquaert and Schermer, 2015).

\subsection{Mediation of hierarchy and status}

Status hierarchies feature in many species. Among humans they are especially prominent in post-Neolithic groups, with most contemporary humans living in highly complex societies (Richerson and Boyd, 1999) that feature great economic inequality (Saez and Zueman, 2014). Drug use can influence and be influenced by status hierarchy, and drugs can mediate political and economic relationships, while both signalling high status and providing solace for those without it.

Drugs are highly prized, and if access is controlled or supply is limited, can confer status on the user and power upon the gatekeeper. Ritual use of entheogens among foragers was restricted to a religious elite, whereas farming societies are characterized by widespread use of drugs with more complex political influences. In complex foraging groups, aspiring "big men" have used drugs as components of competitive feasting, designed to lure potential allies and followers into relationships of debt and political favour (Hayden, 2014). Drugs have been used to compensate and control workers in large-scale societies such as the Incan (Staller, 2009; Morris, 1979), Aztec (Mitchell, 2004), Egyptian, Sumerian and other Near Eastern states (Jennings et al., 2005). Drug were used by European colonizers to induce natives to engage in labour, and then to increase their work efficiency, intensity, and duration (Jankowiak and Bradburd, 1996). Courtwright (2001, p.135) wrote that: "next to profits and taxes, the utility of drugs to acquiring, pacifying and fleecing workers proved to be their greatest advantage to elites". 
Drugs can operate to increase an individual's tolerance of holding low status. They are particularly attractive to those whose status gives them fewer opportunities to receive natural rewards (Nesse, 2002). Social defeat precipitates use of drugs by animals (Bardo et al., 2013, pp. 276-280), including cocaine (Haney et al., 1995) and alcohol (Hilakivi-Clarke and Lister, 1992, Wolffgramm and Heyne, 1991). Comfort foods are used by workers to address effortreward imbalance (Kouvonen et al., 2005) that arises when physical or mental effort is not commensurate with pay and status (Siegrist, 1996). Cameron and Jones (1985) suggest that drugs of solace contribute to maintaining working class compliance. The idea that political hierarchies are facilitated by drug use has been explored also in fiction. Aldous Huxley in Brave New World imagined a society in which ordinary citizens are content with their social roles due to the action of government-supplied "soma" (discussed by Smail, 2007). In Futurological Congress, Stanislaw Lem describes an overpopulated future in which drugs can produce any desired emotion and are added to the water supply to subdue the masses (discussed by Oldani et al., 2014).

Withington (2014) notes the multiple ways in which the "close relationship between intoxication and power" plays out in cultural and political life, with drug use acting as "the lubricant of political patronage; the pledge of ideological loyalty; the rites of manhood; the embodiment of taste, civility, privilege, subordination, and exclusion". He noted that while drugs may console the lowly-ranked, use is certainly not restricted to this stratum but is enjoyed "at all levels of the social hierarchy". It is control of the production and distribution of drugs that confers political power, and this is visible in emergent social complexity (Hayden 2014) and in the contemporary ghetto (Karandinos et al., 2014). Authors in Withington and McShane's (2014) collection provide multiple examples: Shortall (2014) describes counterculture leaders who controlled the supply, method, and meaning of drug use; Sennefelt (2014) describes the role of alcohol gifts in the workings of $18^{\text {th }}$ century Swedish politics, a system which "created a man who knew his place in society and performed his role correctly in relation to other men and in relation to patriarchal norms"; Nugent (2014) describes feasting systems in Africa in which "the ability to supply substantial quantities of beer for collective consumption made a clear statement about the location of power and wealth"; Earle (2014) notes that Incan rulers provided beer in return for the right to assemble communal labour; McShane (2014) describes the necessity of regularly and publicly drinking an oath to prove one's loyalty in $17^{\text {th }}$ century England, noting that even today "the refusal to drink alcohol in company can still elicit a suspicious response".

\subsection{Willingness to work and to accept delayed rewards}

Regular, arduous work for non-immediate payoff is a ubiquitous feature of human life and involves arrangements as varied as farm labour, domestic servitude, factory work and the modern office. Much of what we value in human culture is the result of work; yet most work is aversive to some degree and carries a cost which is perceived subjectively in the form of fatigue or boredom. It is likely that these sensations have evolved to warn individuals of the opportunity cost of work, especially regular, repetitive work (Kurzban et al., 2013). That is to say, fatigue is the result of a cost-benefit calculation which signals to the individual that an alternative expenditure of effort might benefit them more. Fatigue makes it difficult to sustain repetitive effort over long periods of time; yet most people at most times and places, particularly if they hold low rank, have needed to work despite feeling fatigued.

Related to fatigue is impulsivity: both are psychological phenomena that modulate willingness to undertake prolonged effort. Understood as an inclination to value immediate reward and to discount future reward (Green and Myerson, 2004), impulsivity is typically viewed by addiction researchers as both cause and consequence of drug-taking (Stein and 
Madden, 2012; Kirby et al., 1999). But future-discounting and drug use interact in a complex fashion. While long-term addicts may be impulsive (Bickel and Marsh, 2001), drugs can also enable individuals to delay gratification. For example MDMA increases self-control by inducing a feeling of power over delivery of reward (Soubrie, 1986). Opioid users who are currently sated discount the future less than do those who are deprived (Giordano et al., 2002). Individuals who have recently consumed sucrose-laden drinks are more likely to accept delayed rewards (Wang and Dvorak, 2010). Stimulants allow children with ADHD to delay gratification and thereby concentrate on tasks (Reebye and Elbe, 2009).

Drugs have been used throughout human history to motivate workers, to overcome physical and mental fatigue, to inhibit work-related stress, to adapt to work environments and to enhance work performance (Courtwright, 2009; Dube et al., 2005; Grunberg et al., 1999; Jankowiak and Bradburd, 1996; Muller and Schumann, 2011). Organizers in a range of early states provided alcohol, coca and other drugs to workers (Earle, 2014; Staller, 2009; Morris, 1979; Mitchell, 2004; Jennings et al., 2005). Tobacco and coca are used in the contemporary Amazon as a relief or reward after work (Hugh-Jones, 1995). Betel nut is chewed to enhance work in Papua New Guinea (Hirsch, 1995). Kola was provided to work parties of young men in $19^{\text {th }}$ century Sudan to compensate them and combat fatigue (Lovejoy, 1995). Cannabis was smoked by $19^{\text {th }}$ century Indian labourers to obtain relief from work (Mills, 1995). Cocaine and whiskey were given to farm labourers in the $19^{\text {th }}$ century southern United States (Courtwright, 1995). Khat is chewed in the horn of Africa to support work routines, with administration at breakfast and lunch (for energy) and at the end of the working day (for relief) (Klein and Beckerleg, 1995). Kratom is used in South-East Asia to enhance mood during monotonous work (Hassan et al., 2013). Sorghum beer was provided to mine workers in colonial Africa (Nugent, 2014). Alcohol has been provided to personnel in armies and navies since ancient times and formed an important part of military culture, joined later by tobacco and other drugs such as amphetamines, which motivate military personnel by reducing fear and pain during combat and alleviating boredom at other times (Courtwright 2001, p. 140). Drugs and alcohol have traditionally been used to motivate and provide relief to those who perform unpalatable tasks: Courtwright (2001, p.145) lists execution of prisoners, handling of dead bodies, and prostitution as examples. Contemporary university students use stimulants to banish fatigue and make study enjoyable (Petersen, 2015). Prescription drugs are abused by teachers experiencing work-related stress (Wiegel et al., 2015). Comfort foods allow employees to tolerate effort-reward imbalance (Kouvonen et al., 2005). Office workers use caffeine to maintain focus, and then alcohol to adapt to post-work social settings (Muller and Schumann, 2011). Indeed Muller and Schumann (2011) consider high workloads to be a major driver of contemporary drug use.

\subsection{Conditioned salience of cultural phenomena}

Drugs act upon psychological mechanisms of salience and attention; thus they come to be perceived as important, as do settings associated with drug use (Lende and Smith, 2002). People, places, practices and paraphernalia that have been paired with drug use become attractive and stimulate desire for the drug. Cravings can be triggered by a neighbourhood, a building, a drug-using friend, drug equipment, simulated drug preparation, photos of people using drugs, or money (Childress et al., 1993). Furthermore, social and drug rewards interact to create a preference for social settings in which drug use has taken place (Thiel et al., 2008).

The conditioned place preference is used to study the rewarding properties of drugs and other stimuli in animal models (Huston et al., 2013; Prus et al., 2009). In experiments humans also prefer rooms in which they have had enjoyable drug experiences, avoid rooms in which they have had aversive experiences, and show no preference where drug experiences were inconsistent (Childs and deWit, 2010). Conditioned place preference is a form of classical 
conditioning in which a neutral stimulus paired with a rewarding drug becomes attractive in itself (Huston et al., 2013). It is likely partly due to conditioning that drugs "have been fundamental to the nature of sociality and an active element in the construction of religious experience, gender categories and the rituals of social life" (Sherratt, 1995a). Lende (2012) describes ethnographic work that uncovered the roles of salience and habit in the lives of young drug-users in Columbia. Since drug use is associated with many cultural phenomena, particularly those with a social, religious or work element, these settings and activities should be expected to become correspondingly more compelling and engaging.

It should be no surprise then that drug use is intertwined with art and religion. Withington (2014) discusses the connection between art and drugs, discussing two paths of influence: the first being a role in cultural production, the second a role as objects of discussion and representation. Archaeological and anthropological studies provide ample evidence. Osborne (2014) provides an account of the prominence of drinking scenes in ancient Greek art. Withington describes a conflation of creativity and intoxication dating from Islamic poets and Gaelic bards, via the taverns, salons and cafes of Europe to contemporary rock music; at the same time, cultural forms as varied as "printed sermons, tabloid newspapers, political economies, Hollywood movies, Renaissance portraiture, or blogs" have provided a forum for public discussion and representation of the materials, practices, policies, economics and morality of drug use.

Archaeologists can trace the connection between art and drugs back further. VanPool (2009) describes representational practices in shamanist proto-religions around the world and in pre-history. Alongside hallucinogens, shamans use drumming and chanting to achieve altered states of consciousness. Drug-induced experiences such as visual and auditory hallucinations, the sensation of flying and of dying, are portrayed in ancient rock art, paintings and pottery. Visual hallucinations in particular, often consisting of regular geometric patterns of dots, grids or spirals, are a feature of much of the art of forager groups. Extreme nicotine intoxication blocks colour receptors so that users only see white, black and yellow, while peyote boosts perception of certain vivid colours; these influences are visible in ancient art, clothing and pottery. Denizens of the spirit world with which shamans commune are also often depicted. VanPool (2009) discusses the evidence for this in America; similar arguments regarding prehistoric European art are reviewed by Guerra-Doca $(2015$, p. 771). The places in which shamans take drugs, including caves and buildings, assume cultural importance (see VanPool for references and discussion). Global evidence suggests an early association between drugs, religion and art. Subsequent developments into contemporary times provide numerous examples of the influence of drugs upon cultural production.

The presence of drugs and representations thereof in grave goods and tombs also indicates that drugs played significant roles in early religions. Zapata (2004) describes images of poppy capsules in Bronze Age European art and personal ornamentation. Guerra-Doce (2015) describes artistic depictions of psychoactive plants in ancient Mesopotamian, Egyptian, Greek and Etruscan sites. Clarke and Merlin (2013) propose that cannabis influenced the world view and ideology of early humans, precipitating the invention of invisible spirits and becoming a means by which people could communicate with their gods. Chocolate was used in Mayan rituals and beer in Incan religion (Morris, 1979). Drugs continue to serve as sacraments and components of rituals. Alcohol plays a role in Jewish and Christian ceremonies and Chinese ancestor worship (Sherratt, 1995b). Drugs are also regulated by religion (Kirmayer and Raikhel, 2009) and some are banned, though sometimes inconsistently (Matthee, 2014).

The synthesis of new hallucinogens in the mid- $20^{\text {th }}$ century, contemporaneous with a rekindling of interest in ancient mystical uses of psylocibin, renewed interest in the links between drugs and spirituality (Shortall, 2014). While LSD was banned in the 1960s, youth 
interest in drug-enhanced spirituality resurfaced in the rave scene of the 1980s and 90s (JoeLaidler et al., 2014). For many young people, large communal dance parties fuelled by empathogens, hallucinogens, stimulants and disassociatives, sometimes drawing on traditional mystical practices or held in remote sites, represent a new kind of religion (chapters in St John, 2004).

\subsection{Inspiration for trade and colonialism}

Drugs have comprised a significant proportion of commercial trade since ancient times. Van der Geest et al. (1996) argues this is due to a combination of high desirability and convenient physical properties; "their 'thinginess' provides patients and healers with a means to deal with the problem at hand" (p. 154). The potency of drugs relative to their bulk, and their suitability to being packaged and transported, have made drugs powerfully attractive to commercial interests.

David Courtwright in Forces of Habit (2001) provides a detailed account of the expansion of drug commerce from the European discovery of America and development of Atlantic trade networks to the present. He describes a "psychoactive revolution" in which people acquired "more, and more potent, ways of altering their ordinary waking consciousness" (p. 2). The New World drugs brought to Europe were seen initially as exotic medicines but over time became more widely adopted, first for self-medication and then for recreational use. (This pattern has repeated for modern drugs such as heroin and amphetamines.) In the New World, drugs were used to barter with indigenous groups for prized commodities such as furs. Distilled spirits and tobacco were perfect currencies (for the colonists): highly prized by indigenous Americans, their psychoactive effects caused natives to barter less wisely, and addiction played a significant role in the decline of indigenous opposition. Commodities such as tobacco and sugar (much of which was turned into rum) were major components of European and colonial economies, being non-durable goods that enjoyed insatiable demand, leading to ever-expanding trade, infrastructure and workforces (p. 147). Courtwright lists colonialism, trans-Atlantic slavery, industrialization and the building of railroads among the ways in which the drug trade shaped the modern world (2001, p.167).

In the 19th and 20th centuries, vendors of "big three" drugs began to employ advertising to differentiate themselves from competitors, to stimulate demand and to train new users. Mechanized manufacturing and better transport led to the appearance of global markets and a globalized culture emanating from America (Courtwright, 2001, ch. 6). Courtwright, Lovejoy (1995), and Smail (2007) emphasize the social impact of New World drugs upon Europe, with Smail quoting August Ludwig Schlözer (d. 1809) that: "the discovery of spirits, the arrival of tobacco, sugar, coffee and tea in Europe have brought about revolutions just as great as, if not greater than, the defeat of the Invincible Armada, the wars of the Spanish Succession, the Paris Peace, etc".

Psychopharmaceuticals still comprise a significant proportion of world trade, operating at "the highly profitable nexus of science, marketing and human desire" (Oldani, 2014). The use of antidepressants has burgeoned (Elliot and Chambers, 2004), with 11\% of Americans aged 12 and over using selective serotonin reuptake inhibitors (SSRIs) in 2008 (Pratt et al., 2011), and $6 \%$ of American children taking amphetamines such as Adderall to treat ADHD (Visser et al., 2014). Antidepressants are so widely used that it is been proposed that these drugs influence money market trading (Nesse, 2000) and the behaviour of fish after they enter waterways (Guler and Ford, 2010). Following pioneering work by Van der Geest et al. (1996), anthropologists have examined the proliferation of psychopharmaceuticals and its influence upon cultures. A collection edited by Jenkins (2010) asks how cultures are transformed when much of the 
population regularly ingests psychoactive medicines. A special issue of Culture, Medicine and Psychiatry (Oldani and Ecks, 2014) examines their influence on contemporary life, debates around over-prescription and power relationships among drug companies, doctors and patients. Ecks (2014) describes informal "doctors" in rural India who prescribe and dispense antidepressants and are tolerated because they address an enormous treatment gap. Oldani (2014) describes high usage of antidepressants, anxiolytics and antipsychotics in rural and postindustrial areas, and shifting popular understandings of sorrow and anxiety due to drug company campaigns (Oldani, 2014).

\section{Drugs and the human story}

Much of the anthropological work reviewed to this point comprises detailed accounts of instances of drug use in particular cultures. This final section reviews holistic syntheses of the role of drugs in the larger human story.

In On Deep History and the Brain (2007) and An Essay on Neurohistory (2010), Daniel Smail draws from the past thousand years of European history to argue that an increasing range and availability of psychotropic drugs enabled the emergence of new kinds of social control based on manipulating psychological states, which Smail calls "teletropy". He argues that whereas organized state violence is a primitive form of teletropy intended to create stress and submission, the appearance of "movies, gossipy TV shows, novels, music, shopping, sports, coffee, alcohol, drugs, sex, pornography" (p. 161) has enabled a form of governance (which Smail calls "autotropy") in which citizens willingly manipulate their own emotions: "European societies, between the twelfth and the nineteenth centuries, witnessed a tectonic shift away from teletropic mechanisms manipulated by ruling elites toward a new order in which the teletropies of dominance were replaced by the growing range of autotropic mechanisms available on an increasingly unregulated market" (p. 186). If political structures have been shaped by psychotropy, it would appear that mundane, mainstream drug use, and not just addiction, has had important influences on human culture.

The drug instrumentalization framework (Muller and Schumann, 2011) would understand autotropy as a rational response to social pressure to perform acceptable emotions and behaviours. Autotropy is reminiscent also of self-domestication, an idea which several authors propose occurred among humans (Leach 2003). Domestication usually refers to morphological or behavioural change in response to human manipulation of selection pressures. Nesse (2007) proposed that "humans have been domesticated by the preferences and choices of other humans. Individuals who please others get resources and help that increase fitness. Aggressive or selfish individuals get no such benefits and are at risk of exclusion from the group, with dire effects on fitness" (p. 4). Drugs would allow this to occur not just through the slow route of genetic change but in real time, directly changing the social milieu and allowing individuals to adapt to it. Smail notes that the idea that culture devises methods of social control to which we voluntarily succumb is part of an intellectual tradition that includes Karl Marx's Das Kapital, Aldous Huxley's Brave New World (see above), and Neil Postman's Amusing Ourselves to Death. The idea finds early expression in Etienne de la Boétie's (d. 1563) Discourse on voluntary servitude: "theatres, games, plays, spectacles, marvellous beasts, medals, tableaux, and other such drugs were for the people of Antiquity the allurements of serfdom, the price for their freedom, the tools of tyranny".

Courtwright's Forces of Habit (2001) advances two hypotheses: that drugs played a role in inspiring global trade (reviewed in the previous section), and that they served as colonizers' tools for subduing native peoples, giving empire-builders the power to attract, pacify and 
control labourers at home and in colonies and plantations (p. 135). Courtwright notes that opium-smoking Chinese coolies were believed to be the most reliable labourers in the world, while workers in Egypt, Jamaica, Russia and America were paid in alcohol or drugs or spent most of their wages on these, allowing them to tolerate their work while dooming them to an endless cycle of earning and spending. Courtwright argues that the use of drugs as tools of control does not represent a conspiracy by elites, but arises naturally when workers seek drugs which assuage tedium and pain while simultaneously preventing upward mobility.

Though Smail draws mainly upon the historical record, he notes that technologies for psychotropy appeared much earlier: "The effect of the Neolithic transformation, in this neurohistorical perspective, brought about the conditions necessary for a rapid increase in the range of economic, political, and social devices that serve to modulate the body states of self and others." This transition, which occurred at several sites in Asia and America from about 10,000 years ago and subsequently spread to much of the world, involved a number of major changes to human lifeways. The adoption of farming saw drug use expand from infrequent use by religious specialists to regular, widespread use of emotion-regulating drugs such as alcohol, coca and tobacco. Significant changes to social structure and behaviour saw small, mobile, egalitarian forager groups transition to sedentary life in large, hierarchical societies. Some authors have asked whether the appearance both of expanded drug use and complex societies could be linked. Archaeologist Brian Hayden has proposed that cultivation was initially adopted, not for subsistence in the face of food shortages but to support competitive feasting, a practice used for building political power in many traditional societies. Feasting is widespread among complex hunter-gatherer, chieftain and state societies, but not among pre-Neolithic foragers. It is used by ambitious aggrandizers to acquire allies and followers through debt and obligation (Dietler, 2001; Hayden, 2014). Important to successful feasting is the provision of highly-prized commodities such as alcohol. Collective drinking strengthens social bonds and makes psychologically salient the people, places and activities that co-occur with drinking. Hayden (1990) argues that competitive feasting drove the spread of cultivation, subsequently leading to institutionalized farming.

Supporting this hypothesis, Hayden et al. (2012) recently demonstrated that the earliest cereal farmers in the Near East and China were probably brewing alcohol. Similarly, early farmers in America cultivated maize for alcohol (Smalley and Blake, 2003) as well as tobacco (Groark, 2010) and coca (Dillehay, et al. 2010). Wadley and Hayden (2015) argue that expanded drug use supported cultural change by: 1) providing a motive to adopt and maintain cultivation; 2) enhancing pro-sociality, allowing the maintenance and governance of larger, more coordinated groups; 3) instilling acquiescence in and providing solace to subordinates; 4) enticing people into labour arrangements, enhancing their efficiency, and compelling them to keep working. This is similar to the mechanisms proposed by Smail and Courtwright, but occurring earlier and at smaller, more localized scales.

As a tool for successfully negotiating life in large groups, drugs became an important component of a human-constructed "niche", helping subsequent generations adapt to new social environment different to that in which their ancestors evolved (Reid, 2011; Smith, 2011). This niche is due to a manipulation not of the natural environment but the social. The large, relatively stable, coordinated groups that appeared after Neolithization in turn supported further innovation via cumulative technological evolution or "cultural ratcheting" (Tennie et al., 2009). Such groups gained an advantage over rivals because suppression of in-group competition improved the ability to compete with other groups (Alexander, 1987) so that over time farming societies dominated much of the world. As Smail (2007) asserts: "All these changes created, in effect, a new neurophysiological ecosystem, a field of evolutionary adaptation in which the sorts 
of customs and habits that generate new neural configurations or alter brain-body states could evolve in unpredictable ways" (p. 155).

In conclusion, drugs have influenced important aspects of culture from social life to religion, politics to trade, for many thousands of years. By loosening the constraints of inherited behavioural proclivities and encouraging engagement in activities that are not tied to optimal fitness payoffs, drugs broaden the range of behaviour performed. Therefore it can be argued that drugs are not merely components of human culture, but enablers of cultural change.

\section{Acknowledgements}

I am grateful for valuable discussions with David Courtwright, Ed Hagen, Brian Hayden, Andrew Lawrence, Neil Levy, Angus Martin, Christian Mueller and Daniel Smail.

\section{References}

Alexander, R. D. (1987). The biology of moral systems. New Brunswick: Transaction Publishers.

Anderson, P (2006). Global use of alcohol, drugs and tobacco. Drug and Alcohol Review, 25, 489-502.

Anthony, F., M. C. Combes, C. Astorga, B. Bertrand, G. Graziosi, \& P. Lashermes (2002). The Origin of Cultivated Coffea Arabica L. Varieties Revealed by AFLP and SSR Markers. Theoretical and Applied Genetics, 104, 894-900.

Armario, A., J. M. Castellanos, \& J. Balasch. (2008). Effect of Crowding on Emotional Reactivity in Male Rats. Neuroendocrinology, 39:330-333.

Ashton, C. H. (2001). Pharmacology and effects of cannabis: a brief review. British Journal of Psychiatry, 178(2), 101-106.

Baggott, M. J. (2015) Intimate insight: MDMA changes how people talk about significant others. Journal of Psychopharmacology, 29(6) 669-677.

Bardo, M. T., J. L. Neisewander, \& T. H. Kelly. 2013. Individual Differences and Social Influences on the Neurobehavioral Pharmacology of Abused Drugs. Pharmacological Reviews. $65,255-290$.

Bedi, G., D. Hyman, \& H. de Wit. (2010). Is Ecstasy an "Empathogen"? Effects of MDMA on Prosocial Feelings and Identification of Emotional States in Others. Biological Psychiatry, 68, $1134-1140$.

Bellwood, P. (2011). Holocene population history in the Pacific region as a model for worldwide food producer dispersals. Current Anthropology, 52, S363-S378.

Bennett, B. C., \& Alarcón, R. (2015). Hunting and hallucinogens: The use psychoactive and other plants to improve the hunting ability of dogs. Journal of Ethnopharmacology, 171, 171183.

Berridge, K. C. \& T. E. Robinson. (1998). What is the Role of Dopamine in Reward: Hedonic Impact, Reward Learning, or Incentive Salience? Brain Research Reviews, 28:309-369.

Berterame, S. Erthal, J., Thomas, J., Fellner, S., Vosse, B., Clare, P., Hao, W., Johnson, D. T., Mohar, A., Pavadia, J., Samak, A. K. E., Sipp, W., Sumyai, V., Suryawati, S., Toufiq, J., Yans, 
R., Mattick, R. P. (2016), Use of and barriers to access to opioid analgesics: a worldwide, regional, and national study, The Lancet, Available online 3 February 2016, http://dx.doi.org/10.1016/S0140-6736(16)00161-6

Blass, E., E. Fitzgerald, and P. Kehoe. (1987). Interactions Between Sucrose, Pain and Isolation Distress. Pharmacology Biochemistry and Behavior, 26:483-9.

Blum, K., A. L. Chen, J. Giordano, J. Borsten, T. J. Chen, M. Hauser, T. Simpatico, J. Fernino, E. R. Braverman, and D. Barh. (2012). The Addictive Brain: All Roads Lead to Dopamine. Journal of Psychoactive Drugs, 44:134 - 143.

Bickel, W. K., \& L. A. Marsch (2001). Toward a behavioral economic understanding of drug dependence: Delay discounting processes. Addiction, 96:73-86.

Bongard, S., \& Nakajima, M. (2015). Khat chewing and acculturation in East-African migrants living in Frankfurt am Main/Germany. Journal of Ethnopharmacology, 164, 223-228.

Bourgeois, J. A., Parthasarathi, U., \& Hategan, A. (2014). Taking the spice route: Psychoactive properties of culinary spices. Current Psychiatry, 13(4), 21-32.

Brake, M. (1980). The Sociology of Youth Culture and Youth Subcultures: Sex and Drugs and Rock'n'Roll? Oxford: Routledge.

Brown K. J., \& Grunberg N. E. (1995) Effects of housing on male and female rats: crowding stresses males but calms females. Physiology \& Behavior, 58, 1085-1089.

Burchard, R. E.. Coca Chewing and Diet. Current Anthropology. 33(1), 1-24.

Calhoun, J. B. (1973). Death Squared: The Explosive Growth and Demise of a Mouse Population. Proceedings of the Royal Society of Medicine, 66:80-88.

Cameron, D., \& I. G. Jones. (1985). An Epidemiological and Sociological Analysis of the Use of Alcohol, Tobacco and Other Drugs of Solace. Journal of Public Health, 7:18-29.

Chen, J., Wang, P., Xia, Y., Xu, M., and Pei, S. (2005). Genetic diversity and differentiation of Camellia sinensis L.(cultivated tea) and its wild relatives in Yunnan province of China, revealed by morphology, biochemistry and allozyme studies. Genetic Resources and Crop Evolution, 52, 41-52.

Childs, E., \& de Wit, H. (2009). Amphetamine-induced place preference in humans. Biological Psychiatry, 65(10), 900-904.

Childress, A. R., Hole, A. V., Ehrman, R. N., Robbins, S. J., McLellan, A. T., \& O’Brien, C. P. (1993). Cue reactivity and cue reactivity interventions in drug dependence. NIDA Research Monograph Series, 137, 73-73.

Clarke, R. C., \& Merlin, M. D. (2013). Cannabis,. Evolution and Ethnobotany. University of California Press.

Coccurello, R., F. R. D’Amato, and A. Moles. (2009). Chronic Social Stress, Hedonism and Vulnerability to Obesity: Lessons from Rodents. Neuroscience and Biobehavioral Reviews, 33, $537-550$.

Cooper, M. L., M. Russell, J. B. Skinner, M. R. Frone, \& P. Mudar. (1992). Stress and Alcohol Use: Moderating Effects of Gender, Coping, and Alcohol Expectancies. Journal of Abnormal Psychology, 101, 139.

Courtwright, D. T. (2001). Forces of habit: Drugs and the making of the modern world. Cambridge, MA: Harvard University Press. 
Courtwright, D. T. (2010). The NIDA brain disease paradigm: History, resistance and spinoffs. BioSocieties, 5, 137-147.

Courtwright, D. T. (2012). Addiction and the science of history. Addiction, 107(3), 486-492.

Crockett, M. J., Siegel, J. Z., Kurth-Nelson, Z., Ousdal, O. T., Story, G., Frieband, C., GrosseRueskamp, J. M., Dayan, P., \& Dolan, R. J. (2015). Dissociable effects of serotonin and dopamine on the valuation of harm in moral decision making. Current Biology, 25(14), 18521859.

Crocq, M. (2007). Historical and cultural aspects of man's relationship with addictive drugs. Dialogues in Clinical Neuroscience, 9(4), 355-361.

Daniels, J., \& C. Daniels. (1993). Sugarcane in Prehistory. Archaeology in Oceania, 28, 1-7.

Daniels, W. M., C. Y. Pietersen, M. E. Carstens, S. Daya, \& D. Stein. (2000). Overcrowding Induces Anxiety and Causes Loss of Serotonin 5HT-1a R eceptors in Rats. Metabolic Brain Disease, 15, 287-295.

Davis, C., Curtis, C., Levitan, R. D., Carter, J. C., Kaplan, A. S., \& Kennedy, J. L. (2011). Evidence that 'food addiction' is a valid phenotype of obesity. Appetite, 57(3), 711-717.

DeGrandpre, R. (2006). The cult of pharmacology: how America became the world's most troubled drug culture. Duke University Press.

Dietler, M. (1990). Driven by Drink: The Role of Drinking in the Political Economy and the Case of the Early Iron Age in France. Journal of Anthropological Archaeology, 9, 352-406.

Dietler, M. (2001). Theorizing the feast: rituals of consumption, commensal politics, and power in African contexts. In M. Dietler and B. Hayden (Eds.), Feasts, (pp. 65-114). Smithsonian Books: Washington D.C.

Dillehay, T. D., J. Rossen, D. Ugent, A. Karathanasis, V. Va'squez, \& P. J. Netherly. (2010). Early Holocene Coca Chewing in Northern Peru. Antiquity, 84:939-953.

Dube, L., J. L LeBel, \& J. Lu. (2005). Affect Asymmetry and Comfort Food Consumption. Physiology and Behavior, 86, 559-567.

Dudley, R. (2002). Fermenting fruit and the historical ecology of ethanol ingestion: is alcoholism in modern humans an evolutionary hangover?. Addiction, 97(4), 381-388.

Earle, R. (2014). Indians and drunkenness in Spanish America. Past \& Present, 222 (suppl 9), 81-99.

Ecks, S., \& Basu S. (2014). "We always live in fear": Antidepressant prescriptions by unlicensed doctors in India. Culture, Medicine, and Psychiatry, 38, 197-216.

Elliott, C., \& Chambers, T., Eds. (2004). Prozac as a Way of Life. Chapel Hill: UNC Press.

Epstein, Y. M. (1981). Crowding Stress and Human Behavior. Journal of Social Issues, 37, $126-144$.

Farah, M. J., Illes, J., Cook-Deegan, R., Gardner, H., Kandel, E., King, P., Parens, E., Sahakian, B., \& Wolpe, P. R. (2004). Neurocognitive enhancement: what can we do and what should we do?. Nature Reviews Neuroscience, 5(5), 421-425.

Focquaert, F., \& Schermer, M. (2015). Moral Enhancement: Do Means Matter Morally? Neuroethics, 8(2), 139-151.

Fulde, G. W. O., \& Forster, S. L. (2015). The impact of amphetamine-type stimulants on emergency services. Current Opinion in Psychiatry, 28, 275-279. 
Fuller, D. Q. (2005). Ceramics, Seeds and Culinary Change in Prehistoric India. Antiquity, 79, 761-777.

Garriott, W., \& Raikhel, E. (2015). Addiction in the Making. Annual Review of Anthropology, $44,477-491$.

Glannon, W. (2006). Psychopharmacology and memory. Journal of Medical Ethics, 32(2), 7478 .

Glantz, M. D. (2013). The terminology of addictive behavior. In Miller, P. (Ed.) Principles of Addiction: Comprehensive Addictive Behaviors and Disorders volume 1. (pp 13-22). Academic Press: San Diego.

Gibson, E. L. (2012). The Psychobiology of Comfort Eating: Implications for Neuropharmacological Interventions. Behavioral Pharmacology, 23, 442-460.

Giordano, L. A., W. K. Bickel, G. Loewenstein, E. A. Jacobs, L. Marsch, and G. J. Badger. (2002). Mild Opioid Deprivation Increases the Degree That Opioid-Dependent Outpatients Discount Delayed Heroin and Money. Psychopharmacology, 163, 174-182.

Goodman, J. (1995). Excitantia: Or, how enlightenment Europe took to soft drugs. Consuming Habits: Goodman, J., Lovejoy, P. E., \& Sherratt, A. Eds. (1995). Consuming Habits: Drugs in History and Anthropology. (pp. 121-141). London: Routledge.

Goodman, J., Lovejoy, P. E. , \& Sherratt, A. Eds. (1995). Consuming Habits: Drugs in History and Anthropology. London: Routledge.

Gowing, L. R. (2014). Global statistics on addiction behaviours: 2014 status report. Addiction, 110(6), 904-919.

Green, L., \& J. Myerson. (2004). A Discounting Framework for Choice with Delayed and Probabilistic Rewards. Psychological Bulletin, 130, 769.

Griffiths, R. R., Richards, W. A., McCann, U., \& Jesse, R. (2006). Psilocybin can occasion mystical-type experiences having substantial and sustained personal meaning and spiritual significance. Psychopharmacology, 187(3), 268-283.

Grivet, L., C. Daniels, J. C. Glaszmann, \& A. D’Hont (2004). A Review of Recent Molecular Genetics Evidence for Sugarcane Evolution and Domestication. Ethnobiology Research and Applications, 2, 9-17.

Groark, K. P. (2010). The Angel in the Gourd: Ritual, Therapeutic, and Protective Uses of Tobacco (Nicotiana tabacum) Among the Tzeltal and Tzotzil Maya of Chiapas, Mexico. Journal of Ethnobiology, 30, 5-30.

Grob, C. S., Bossis, A. P., \& Griffiths, R. R. (2013). Use of the classic hallucinogen psilocybin for treatment of existential distress associated with cancer. In Carr, B. I. \& Steel, J. (Eds.) Psychological Aspects of Cancer. (pp. 291-308). Springer US.

Grunberg, L., S. Moore, R. Anderson-Connolly, \& E. Greenberg. (1999). Work Stress and SelfReported Alcohol Use: The Moderating Role of Escapist Reasons for Drinking. Journal of Occupational Health Psychology, 4, 29.

Guerra-Doce, E. (2015). The origins of inebriation: Archaeological evidence of the consumption of fermented beverages and drugs in prehistoric Eurasia. Journal of Archaeological Method and Theory, 22 (3), 751-782.

Guler, Y., \& Ford, A. T. (2010). Anti-depressants make amphipods see the light. Aquatic Toxicology. http://10.1016/j.aquatox.2010.05.019 
Guthrie, J. S., \& Ho-Yen, D. O.. (2011). Alcohol and Cholera. Journal of the Royal Society of Medicine 104, 98.

Ilieva, I. (2015). Enhancement of healthy personality through psychiatric medication: The influence of SSRIs on neuroticism and extraversion. Neuroethics, 8(2), 127-137.

Hagen, E. H., Roulette, C. J., \& Sullivan, R. J. (2013). Explaining human recreational use of 'pesticides.' Frontiers in Psychiatry, 4, 142.

Haney, M., S. Maccari, M. Le Moal, H. Simon, \& P. Vincenzo Piazza. (1995). Social Stress Increases the Acquisition of Cocaine Self-Administration in Male and Female Rats. Brain Research, 698, 46-52.

Harris, M. (1968). The rise of anthropological theory: A history of theories of culture. Walnut Creek: Altamira Press.

Hassan, Z., Muzaimi, M., Navaratnam, V., Yusoff, N. H., Suhaimi, F. W., Vadivelu, R., Vicknasingam, B. K., Amatoc, D., von Hörstend, S., Ismail, N. I. W., Jayabalan, N., Hazima, A. I., Mansor, S. M., Müller, C. P. (2013). From Kratom to mitragynine and its derivatives: physiological and behavioural effects related to use, abuse, and addiction. Neuroscience \& Biobehavioral Reviews, 37(2), 138-151.

Hayden, B. (2014). The Power of Feasts. Cambridge: Cambridge University Press.

Hayden, B., Canuel, N., \& Shanse, J. (2012). What was brewing in the natufian? an archaeological assessment of brewing technology in the Epipaleolithic. Journal of Archaeological Method and Theory, 20, 102-150.

Heath D. (1958). Drinking patterns of the Bolivian Camba. Quarterly Journal of Studies on Alcohol, 19, 491-508.

Hendricks, P. S. (2015) Classic psychedelic use is associated with reduced psychological distress and suicidality in the United States adult population. Journal of Psychopharmacology, 29(3), 280-288.

Hilakivi-Clarke, L., and R. G. Lister (1992). Social Status and Voluntary Alcohol Consumption in Mice: Interaction With Stress. Psychopharmacology, 108, 276-282.

Hirsch, E. (1995). Betelnut 'bisnis' and cosmology: A view from Papua New Guinea. In Goodman, J., P. E. Lovejoy, \& Sherratt, A., Eds. (1995). Consuming Habits: Drugs in History and Anthropology. (pp. 67-87). Routledge, London.

Hugh-Jones, S. (1995). Coca, beer, cigars and yage: meals and anti-meals in an Amerindian community. In J. Goodman, P. E. Lovejoy \& A. Sherratt (Eds.), Consuming Habits: Drugs In History and Anthropology (pp. 47-65). Routledge, London.

Hussey, A. (2013). Heroin: art and culture's last taboo. The Guardian 22 Dec 2013. Accessed at http://www.theguardian.com/tv-and-radio/2013/dec/22/art-heroin-christiane-f .

Huston, J. P., de Souza Silva, M. A., Topic, B., \& Müller, C. P. (2013). What's conditioned in conditioned place preference? Trends in Pharmacological Sciences, 34(3), 162-166.

Hsu, H. B. (2014). The Taste of Opium: Science, Monopoly, and the Japanese Colonization in Taiwan, 1895-1945. Past \& Present, 222 (suppl 9), 227-246.

Ifland, J. R., Preuss, H. G., Marcus, M. T., Rourke, K. M., Taylor, W. C., Burau, K., Jacobse, W.S., Kadish, W., \& Manso, G. (2009). Refined food addiction: a classic substance use disorder. Medical Hypotheses, 72(5), 518-526. 
Ilieva, I. (2015). Enhancement of Healthy Personality Through Psychiatric Medication: The Influence of SSRIs on Neuroticism and Extraversion. Neuroethics, 8(2), 127-137.

Ioannidis, K., Chamberlain, S. R., \& Müller, U. (2014). Ostracising caffeine from the pharmacological arsenal for attention-deficit hyperactivity disorder - was this a correct decision? A literature review. Journal of Psychopharmacology, 28, 830-836.

Jankowiak, W., \& Bradburd, D. (1996). Using drug foods to capture and enhance labor performance: A cross-cultural perspective. Current Anthropology, 37, 717-720.

Jenkins, J. (2010). Introduction. In Jenkins, J., Ed. Pharmaceutical Self: the Global Shaping of Experience in an Age of Psychopharmacology. Santa Fe: SAR Press.

Jennings, J., K. Antrobus, S. Atencio, E. Glavich, R. Johnson, G. Loffler, \& C. Luu. (2005). Drinking Beer in a Blissful Mood: Alcohol Production, Operational Chains, and Feasting in the Ancient World. Current Anthropology, 46, 275-303.

Joe-Laidler, K., Hunt, G., \& Moloney, M. (2014). 'Tuned Out or Tuned In': Spirituality and Youth Drug Use in Global Times. Past \& Present, 222 (suppl 9), 61-80.

Johnson P, \& P. J. Kenny (2010). Dopamine D2 Receptors in Addiction-Like Reward Dysfunction and Compulsive Eating in Obese Rats. Nature Neuroscience, 13, 635-41.

Karandinos, G., Hart, L. K., Castrillo, F. M., \& Bourgois, P. (2014). The moral economy of violence in the US inner city. Current Anthropology, 55(1), 1.

Kasanetz, F., Deroche-Gamonet, V., Berson, N., Balado, E., Lafourcade, M., Manzoni, O., \& Piazza, P. V. (2010). Transition to addiction is associated with a persistent impairment in synaptic plasticity. Science, 328(5986), 1709-1712.

Kehoe, A. B. (2013). Humans: an Introduction to Four-Field Anthropology. London: Routledge.

Kenakin, T. (2004). Principles: Receptor theory in pharmacology. Trends in Pharmacological Sciences, 25(4), 186-192.

Kennedy, D. O. (2014). Plants and the Human Brain. Oxford: Oxford University Press.

Kirby, K. N., Petry, N. M., \& Bickel, W. K. (1999). Heroin addicts have higher discount rates for delayed rewards than non-drug-using controls. Journal of Experimental Psychology: General, 128(1), 78.

Kirkpatrick, M. (2015) Prosocial effects of MDMA: A measure of generosity. Journal of Psychopharmacology, 29 (6), 661-668.

Kirmayer, L., \& Raikhel, E. (2009). From Amrita to Substance D: psychopharmacology, Political Economy, and Technologies of the Self. Transcultural Psychiatry, 46(1): 5-15.

Kitayama, S., \& Uskul, A. K. (2011). Culture, mind, and the brain: Current evidence and future directions. Annual Review of Psychology, 62, 419-449.

Klein, A., \& Beckerleg, S. (1995). Building castles of spit-the role of Khat chewing in Worship, work and leisure. In Goodman, J., P. E. Lovejoy \& Sherratt, A., Eds. (1995). Consuming Habits: Drugs in History and Anthropology. (pp. 67-87). London: Routledge.

Koob, G. F., \& Le Moal, M. (2001). Drug addiction, dysregulation of reward, and allostasis. Neuropsychopharmacology, 24, 97-129.

Koob, G. F., \& Mason, B. J. (2016) Existing and Future Drugs for the Treatment of the Dark Side of Addiction. Annual Review of Pharmacology and Toxicology. Review in Advance, posted online on October 22, 2015. 
Korpi, E. R., den Hollander, B., Farooq, U., Vashchinkina, E., Rajkumar, R., Nutt, D. J., Hyytiä, P., \& Dawe, G. S. (2015). Mechanisms of Action and Persistent Neuroplasticity by Drugs of Abuse. Pharmacological Reviews, 67(4), 872-1004. doi: 10.1124/pr.115.010967

Kouvonen, A., M. Kivimaki, S. J. Cox, T. Cox, and J. Vahtera (2005). Relationship Between Work Stress and Body Mass Index Among 45,810 Female and Male Employees. Psychosomatic Medicine, 67, 577-583.

Kurzban, R., Burton-Chellew, M. N., \& West, S. A. (2015). The evolution of altruism in humans. Annual Review of Psychology, 66, 575-599.

Kurzban, R., Duckworth, A., Kable, J. W., \& Myers, J. (2013). An opportunity cost model of subjective effort and task performance. Behavioral and Brain Sciences, 36(6), 661-679.

Kushner, H. (2010) Toward a cultural biology of addiction. BioSocieties, 5, 8-24.

Leach, H. M. (2003). Human domestication reconsidered. Current Anthropology, 44(3), 349368.

Leedy, G. M., Barrows, L. F., \& Clark, S. (2013). Effects of social housing on hippocampal dendrites and behavior in ovariectomized rats. Brain Research Bulletin, 92, 69-75.

Lende, D. H. (2012). Addiction and Neuroanthropology. In Lende, D. H. \& Downey, G. (2012). The Encultured Brain: an Introduction to Neuroanthropology. (pp. 339-362). MIT Press.

Lende, D. H., \& Downey, G. (2012). The Encultured Brain: an Introduction to Neuroanthropology. Cambridge, MA: MIT Press.

Lende, D. H., \& E. O. Smith. (2002). Evolution Meets Biopsychosociality: An Analysis of Addictive Behavior. Addiction, 97, 447-458.

Lende, D.H., Leonard, T., Sterk, C.E., \& Elifson, K. (2007) Functional methamphetamine use: The insider's perspective. Addiction Research and Therapy, 15(5), 465477.

Lenoir, M., Serre, F., Cantin, L., \& Ahmed, S. H. (2007). Intense sweetness surpasses cocaine reward. PloS one, 2(8), e698. DOI: 10.1371/journal.pone.0000698

Leri, F., \& Levy, A. M. (2015). Is high fructose corn syrup addictive? Studies of operant intraoral self-administration in rats. Drug \& Alcohol Dependence, 146, e174.

Levinthal, C. F. (1988). Messengers of Paradise. New York: Doubleday.

Levy, N., Douglas, T., Kahane, G., Terbeck, S., Cowen, P. J., Hewstone, M., \& Savulescu, J. (2014). Are you morally modified?: The moral effects of widely used pharmaceuticals. Philosophy, Psychiatry \& Psychology. 21(2), 111-125. doi: 10.1353/ppp.2014.0023

Lo, V., Kadetz, P., Datiles, M. J. R., \& Heinrich, M., Eds. (2015) Journal of Ethnopharmacology. Special issue: "Potent Substances: On the Boundaries of Food and Medicine". June 2015.

Lovejoy, P. E. (1980). Kola in the History of West Africa. Cahiers d'Etudes africaines 20, 97134.

Lovejoy, P. E. (1995). Kola nuts, the "coffee" of the central Sudan. In Goodman, J., P. E. Lovejoy \& Sherratt, A., Eds. (1995). Consuming Habits: Drugs in History and Anthropology. (pp. 103-125). London: Routledge. 
Majić, T., Schmidt, T. T., Gallinat, J. (2015). Peak experiences and the afterglow phenomenon: When and how do therapeutic effects of hallucinogens depend on psychedelic experiences? Journal of Psychopharmacology, 29(3), 241-253.

Maoz, H., Tsviban, L., Gvirts, H. Z., Shamay-Tsoory, S. G., Levkovitz, Y., Watemberg, N., \& Bloch, Y. (2014). Stimulants improve theory of mind in children with attention deficit/hyperactivity disorder. Journal of Psychopharmacology, 28(3), 212-219.

Martinotti, G., M. D. Nicola, D. Tedeschi, S. Cundari, \& L. Janiri. (2009). Empathy Ability is Impaired in Alcohol-Dependent Patients. The American Journal on Addictions, 18, 157-161.

Matthee, R. (2014) Alcohol in the Islamic Middle East: Ambivalence and Ambiguity. Past and Present, 222 (suppl 9), 100-125. doi:10.1093/pastj/gtt031

McGovern, P. E., J. Zhang, J. Tang, Z. Zhang, G. R. Hall, R. A. Moreau and C. Wang. (2004). Fermented Beverages of Pre- and Proto-Historic China. Proceedings of the National Academy of Sciences of the United States of America, 101, 17593-17598.

Merlin, M. D. (2003). Archaeological Evidence for the Tradition of Psychoactive Plant Use in the Old World. Economic Botany, 57, 295-323.

Mills, J. H. (1995). Globalizing ganja: the British Empire and international cannabis traffic c. 1834 to c. 1939. In Goodman, J., P. E. Lovejoy \& Sherratt, A., Eds. (1995). Consuming Habits: Drugs in History and Anthropology. (pp. 67-87). London: Routledge.

Miller, P. Ed. (2013) Principles of Addiction: Comprehensive Addictive Behaviors and Disorders, Volume 1. Cambridge: Academic Press.

Mitchell, T. J. (2004). Intoxicated Identities: Alcohol's Power In Mexican History and Culture. New York: Routledge.

Moore, D. (2004). Beyond "subculture" in the ethnography of illicit drug use. Contemporary Drug Problems, 31(2), 181-212.

Morgan, C. J., L. A. Noronha, M. Muetzelfeldt, A. Fielding, and H. V. Curran. (2013). Harms and Benefits Associated with Psychoactive Drugs: Findings of an International Survey of Active Drug Users. Journal of Psychopharmacology, 27, 497-506.

Morris, C. (1979). Maize beer in the economics, politics, and religion of the Inca empire. In C. Gastineau, W. Darby, and T. Turner (Eds.) Fermented Foods in Nutrition (pp. 21-34). New York: Academic Press.

Muehlmann, S. (2013). When I Wear My Alligator Boots: Narco-Culture In The US Mexico Borderlands. Berkeley: University of California Press.

Muller, C. P., \& Schumann, G. (2011). Drugs as instruments: A new framework for nonaddictive psychoactive drug use. Behavioral and Brain Sciences, 34, 293-310.

Mueller, D., \& de Wit, H. (2011). Conditioned place preference in rodents and humans. In Raber, J. Ed. Animal Models of Behavioral Analysis. (pp. 133-152). New York: Humana Press.

Nagaraja, H. S., and P. S. Jeganathan. (2003). Effect of Acute and Chronic Conditions of Overcrowding on Free Choice Ethanol Intake in Rats. Indian Journal of Physiology and Pharmacology, 47, 325-331.

Naitoh, H., S. Nomura, Y. Kunimi, and K. Yamaoka. (1992). "Swimming-Induced Head Twitching" in Rats in the Forced Swimming Test Induced by Overcrowding Stress: A New Marker in the Animal Model of Depression? The Keio Journal of Medicine, 41, 221. 
Nesse, R. M. (2000). Is the Market on Prozac? The Edge website. Retrieved from http://edge.org/3rd_culture/story/100.html on 16th February 2016.

Nesse, R. M. 2002. Evolution and Addiction. Addiction, 97, 470-471.

Nesse, R. M. (2007). Runaway social selection for displays of partner value and altruism. Biological Theory 2(2) 2007, 1-13..

Nesse, R. M., \& Berridge, K. C. (1997). Psychoactive Drug Use in Evolutionary Perspective. Science, 278, 64-65.

Norton, S. A. (1998). Betel: consumption and consequences. Journal of the American Academy of Dermatology, 38(1), 81-88.

Nugent, P. (2014). Modernity, tradition, and intoxication: Comparative lessons from South Africa and West Africa. Past \& Present, 222 (suppl 9), 126-145.

Nutt, D. J., Lingford-Hughes, A., Erritzoe, D., \& Stokes, P. R. A. (2015). The dopamine theory of addiction: 40 years of highs and lows. Nature Reviews Neuroscience, 16, 305-312.

Odenwald, M., Klein, A., \& Warfa, N. (2010). Introduction to the special issue: the changing use and misuse of khat (Catha edulis) - tradition, trade and tragedy. Journal of Ethnopharmacology, 132(3), 537-539.

Oldani, M. (2014) Deep Pharma: Psychiatry, Anthropology and Pharmaceutical Detox. Culture, Medicine and Psychiatry, 38(2), 174.

Oldani, M., \& Ecks, S. (2014). Special issue on Humanness and Modern Psychotropy. Culture, Medicine and Psychiatry, 38(2).

Oldani, M., Ecks, S., \& Basu, S. (2014). Anthropological engagements with modern psychotropy. Culture, Medicine and Psychiatry, 38(2), 174.

Osborne, R. (2014). Intoxication and Sociality: The Symposium in the Ancient Greek World. Past \& Present, 222 (suppl 9), 34-60.

Pechlivanova, D. M., J. D. Tchekalarova, L. H. Alova, V. V. Petkov, R. P. Nikolov, \& K. S. Yakimova (2012) Effect of Long-Term Caffeine Administration on Depressive-Like Behavior in Rats Exposed to Chronic Unpredictable Stress. Behavioral Pharmacology, 23, 339-347.

Petersen, M. A. (2015). Pursuing pleasures of productivity: university students' use of prescription stimulants for enhancement and the moral uncertainty of making work fun. Culture, Medicine, and Psychiatry 39(4), 665-679.

Pickard, H. (2012). The Purpose in Chronic Addiction. AJOB Neuroscience, 3, 40-49.

Pieters, T., \& Snelders, S. (2009). Psychotropic drug use: Between healing and enhancing the mind. Neuroethics, 2(2), 63-73.

Plowman, T. (1984). The Origin, Evolution, and Diffusion of Coca, Erythroxylum spp., in South and Central America in Pre-Columbian Plant Migration. Papers of the Peabody Museum of Archaeology and Ethnology Cambridge, 76, 125-163.

Polivy, J., Herman, C. P., \& Coelho, J. S. (2008). Caloric restriction in the presence of attractive food cues: external cues, eating, and weight. Physiology \& Behavior, 94(5), 729-733.

Pontieri, F. E., Tanda, G., Orzi, F., \& Di Chiara, G. (1996). Effects of nicotine on the nucleus accumbens and similarity to those of addictive drugs. Nature, 382, 255 - 257 (18 July 1996); doi: $10.1038 / 382255 \mathrm{a} 0$ 
Powis, T. G., F. Valdez Jr, T. R. Hester, W. J. Hurst, \& S. M. Tarka Jr. (2002). Spouted Vessels and Cacao Use Among the Preclassic Maya. Latin American Antiquity, 13, 85 - 106.

Pratt, L. A., Brody, D. J., \& Gu, Q. (2011). Antidepressant use in persons aged 12 and over: United States, 2005-2008. NCHS Data Brief No. 76, October 2011, Centers for Disease Control and Prevention.

Price, J. M. (1995). Tobacco use and tobacco taxation: A battle of interests in early modern Europe. In Goodman, J., P. E. Lovejoy \& A. Sherratt, Eds. (1995). Consuming Habits: Drugs in History and Anthropology. (pp. 166-169). London: Routledge.

Prus, A. J., James, J. R., \& Rosecrans, J. A. (2009). Conditioned place preference. In Buccafusco J. J., Ed. Methods of Behavior Analysis in Neuroscience. 2nd edition. Boca Raton: CRC Press/Taylor \& Francis.

Rafferty, S. M. 2006. Evidence of Early Tobacco in Northeastern North America? Journal of Archaeological Science, 33, 453-458.

Reebye, P. N., \& Elbe, D. (2009). The role of pharmacotherapy in the management of selfregulation difficulties in young children. Journal of the Canadian Academy of Child \& Adolescent Psychiatry, 18(2).

Reid, A. (2011) Drug addiction finds its own niche. Response to Muller, C. P., \& Schumann, G. (2011). Drugs as instruments: A new framework for non-addictive psychoactive drug use. Behavioral and Brain Sciences, 34, 293-310.

Richards, J. (2014). Health, Intoxication, and Civil Conversation in Renaissance England. Past \& Present, 222(suppl 9), 168-186.

Richerson, P. J., \& Boyd, R. (1999). Complex societies. Human Nature, 10(3), 253-289.

Richerson, P. J., Boyd, R., \& Henrich, J. (2010). Gene-culture coevolution in the age of genomics. Proceedings of the National Academy of Sciences, 107 (Supplement 2), 8985-8992.

Robinson, T. E. \& K. C. Berridge. (1993). The Neural Basis of Drug Craving: An IncentiveSensitization Theory of Addiction. Brain Research Reviews, 18, 247-291.

Roulette, C. J., Mann, H., Kemp, B. M., Remiker, M., Roulette, J. W., Hewlett, B. S., Kazangi, M., Breurec, S., Monchy, D., Sullivan, R. J. \& Hagen, E. H. (2014). Tobacco use vs. helminths in Congo basin hunter-gatherers: self-medication in humans? Evolution and Human Behavior, 35(5), 397-407.

Rudgley, R. (1995). The Archaic Use of Hallucinogens in Europe: An Archaeology of Altered States. Addiction, 90, 163-4.

Saez, E., \& Zucman, G. (2014). Wealth inequality in the United States since 1913: Evidence from capitalized income tax data. NBER Working Paper No. 20625. National Bureau of Economic Research.

Saniotis, A. (2010). Evolutionary and anthropological approaches towards understanding human need for psychotropic and mood altering substances. Journal of Psychoactive Drugs, 42, 477484.

Schultes, R. E. (1969). The Plant Kingdom and Hallucinogens (Part I). Bulletin on Narcotics, 21 (3), 3- 16.

Sennefelt, K. (2014). Wine, corruption, and the politics of intoxication in eighteenth-century Stockholm. Past \& Present, 222 (suppl 9), 277-295. 
Sherratt, A. (1995a). Introduction: Peculiar Substances. In Goodman, J., P. E. Lovejoy \& A. Sherratt, Eds. (1995). Consuming Habits: Drugs in History and Anthropology. (pp 1-10). London: Routledge.

Sherratt, A. 1995b. Alcohol and Its Alternatives: Symbol and Substance in Pre-Industrial Cultures. In Goodman, J., P. E. Lovejoy \& A. Sherratt, Eds. (1995). Consuming Habits: Drugs in History and Anthropology. (pp. 11-46). London: Routledge.

Shortall, S. (2014) Psychedelic Drugs and the Problem of Experience. Past and Present. 222 (suppl 9), 187-206. doi:10.1093/pastj/gtt035

Siegrist, J. (1996). Adverse Health Effects of High-Effort/Low-Reward Conditions. Journal of Occupational Health Psychology, 1, 27.

Silcock, J. L., Tischler, M., \& Smith, M. (2012). Quantifying the Mulligan River Pituri Trade of Central Australia. Ethnobotany Research \& Applications, 10, 37-44.

Singer, M. (2012). Anthropology and addiction: an historical review. Addiction, 107(10), 174755.

Sinha, R. (2001). How Does Stress Increase Risk of Drug Abuse and Relapse? Psychopharmacology, 158, 343-359.

Skewes, M. C., \& Gonzelez, V. M. (2013) The biopsychosocial model of addiction. In Miller, P. (Ed.) Principles of Addiction: Comprehensive Addictive Behaviors and Disorders volume 1, Academic Press: San Diego.

Smail, D. L. (2007). On deep history and the brain. Oakland: University of California Press.

Smail, D. L. (2010) An Essay on Neurohistory. In Bailar, M. Ed. Emerging Disciplines: Shaping New Fields of Scholarly Inquiry in and beyond the Humanities. (pp. 201-228) Houston: Rice University Press.

Smalley, J., \& M. Blake. (2003). Sweet Beginnings: Stalk Sugar and the Domestication of Maize. Current Anthropology, 44, 675-703.

Smith, A. P. (2013). Caffeine, extraversion and working memory. Journal of Psychopharmacology, 27, 71-76.

Smith, B. D. (2011). A cultural niche construction theory of initial domestication. Biological Theory, 6(3), 260-271.

Smith, W. D. (1995) . From coffeehouse to parlour: the consumption of coffee, tea and sugar in north-western Europe in the seventeenth and eighteenth centuries. In Goodman, J., P. E. Lovejoy \& Sherratt, A., Eds. (1995). Consuming Habits: Drugs in History and Anthropology. (pp. 142-157). London: Routledge.

Soubrie, P. (1986). Reconciling the role of central serotonin neurones in human and animal behavior. Behavioral and Brain Sciences, 9, 319-364.

Sõukand, R., Pieroni, A., Biró, M., Dénes, A., Dogan, Y., Hajdari, A., Kallea, R., Readeh, B., Mustafaf, B., Nedelchevai, A., Quave, C. L., Łuczajl, L. (2015). An ethnobotanical perspective on traditional fermented plant foods and beverages in Eastern Europe. Journal of Ethnopharmacology, 170, 284-296.

St John, G. Ed. (2004). Rave culture and religion. London: Routledge.

Staller, J. (2009). The Social, Symbolic, and Economic Significance of Zea mays L. in the Late Horizon Period. In J. Staller, R. Tykot, and B. Benz. Eds. Histories of Maize: Multidisciplinary 
Approaches to the Prehistory, Linguistics, Biogeography, Domestication, and Evolution of Maize. Walnut Creek, CA: Left Coast Press. (pp. 449-467).

Stein, I. S. \& G. I. Madden (2012). Delay Discounting and Drug Abuse: Empirical, Conceptual, and Methodological Considerations. In J. MacKillop and H. De Wit, Eds. The Wiley-Blackwell Handbook of Addiction Psychopharmacology. (pp. 165). Chichester: John Wiley.

Stewart, L. H., Ferguson, B., Morgan, C. J. A. , Swaboda, N., Jones, L., Fenton, R., Wall, M. B., \& Curran, H. V. (2014). Effects of ecstasy on cooperative behaviour and perception of trustworthiness: A naturalistic study. Journal of Psychopharmacology, 28, 1001-100.

Stolt, A. C., Schröder, H., Neurath, H., Grecksch, G., Höllt, V., Meyer, M. R., Maurer, H. H., Ziebolz, N., Havemann-Reinekce, U., \& Becker, A. (2014). Behavioral and neurochemical characterization of kratom (Mitragyna speciosa) extract. Psychopharmacology, 231(1), 13-25.

Stromberg, P. G. (2012). Collective Excitement and Lapse in Agency: Fostering an Appetite for Cigarettes. In Lende, D. H., \& Downey, G. (2012). The Encultured Brain: an Introduction to Neuroanthropology. (pp. 315-338). Cambridge, MA: MIT Press.

Sullivan, R. J., \& Hagen, E. H. (2002). Psychotropic substance-seeking: Evolutionary pathology or adaptation? Addiction, 97, 389- 400.

Tennie, C., Call, J., \& Tomasello, M. (2009). Ratcheting up the ratchet: on the evolution of cumulative culture. Philosophical Transactions of the Royal Society of London B: Biological Sciences, 364(1528), 2405-2415.

Thakker, J. K. (2013). International perspectives on addiction. In Miller, P. (Ed.) Principles of Addiction: Comprehensive Addictive Behaviors and Disorders volume 1. (pp 51-59). San Diego: Academic Press.

Thiel, K. J., Okun, A. C., \& Neisewander, J. L. (2008). Social reward-conditioned place preference: a model revealing an interaction between cocaine and social context rewards in rats. Drug and Alcohol Dependence, 96(3), 202-212.

Thomas, B. (2003). The Psychoactive Flora of Papua New Guinea. Journal of Psychoactive Drugs, 35, 285-293.

Todd, M. (2004). Daily Processes in Stress and Smoking: Effects of Negative Events, Nicotine Dependence, and Gender. Psychology of Addictive Behaviors, 18, 31-39.

Trezza, V., R. Damsteegt, E. M. Achterberg, \& L. J. Vanderschuren. 2011. Nucleus Accumbens m-opioid Receptors Mediate Social Reward. The Journal of Neuroscience, 31, 6362-6370.

Ulrich-Lai, Y. M., A. M. Christiansen, M. M. Ostrander, A. A. Jones, K. R. Jones, D. C. Choi, \& J. P. Herman. (2010). Pleasurable Behaviors Reduce Stress Via Brain Reward Pathways. Proceedings of the National Academy of Sciences, 107, 20529-20534.

United Nations (2012). World Urbanization Prospects, the 2011 Revision. United Nations Department of Economic and Social Affairs/Population Division.

Van der Geest, S., Whyte, S. R., \& Hardon, A. (1996). The anthropology of pharmaceuticals: a biographical approach. Annual Review of Anthropology, 25, 153-178.

VanPool, C. S. (2009). The Signs of the Sacred: Identifying Shamans Using Archaeological Evidence. Journal of Anthropological Archaeology, 28, 177-190.

Velea, D. and M. Hautefeuille. (2007). Empathogenic Agents: Their Use, Abuse, Mechanism of Action and Addiction Potential. In T. Farrow and P. Woodruff, Eds. Empathy In Mental Illness. (pp. 289-309). Cambridge University Press, Berkeley. 
Visser, S. N., Danielson, M. L., Bitsko, R. H., Holbrook, J. R., Kogan, M. D. Ghandour, R. M., Perou, R., Blumberg, S. J. (2014). Trends in the Parent-Report of Health Care ProviderDiagnosed and Medicated Attention-Deficit/Hyperactivity Disorder: United States, 2003-2011. Journal of the American Academy of Child and Adolescent Psychiatry, 53(1), 34-46.e2.

Volkow, N. D., \& Wise, R. A. (2005). How can drug addiction help us understand obesity? Nature Neuroscience, 8(5), 555-560.

Volkow, N. D., Wang, G-J., Fowler, J. S., \& Tomasi, D. (2012) Addiction circuitry in the human brain. Annual Review of Pharmacology and Toxicology, 52, 321-336.

Von Gernet, A. 1995. Nicotian Dreams: The Prehistory and Early History Of Tobacco in Eastern North America. In Goodman, J., P. E. Lovejoy \& Sherratt, A., Eds. (1995). Consuming Habits: Drugs in History and Anthropology. (pp. 67-87). London: Routledge.

Wadley, G., \& Hayden, B. (2015). Pharmacological Influences on the Neolithic Transition. Journal of Ethnobiology, 35(3), 566-584.

Wang, X. T., \& R. D. Dvorak. (2010). Sweet Future: Fluctuating blood glucose levels affect future discounting. Psychological Science, 21, 183-188.

Wansink, B., M. M. Cheney, \& N. Chan. (2003). Exploring Comfort Food Preferences Across Age and Gender. Physiology and Behavior, 79, 739-747.

Weinberg D. (2011). Sociological perspectives on addiction. Sociology Compass, 5(4), 298 310 .

Westermeyer (2013). Historical understandings of addiction. In Miller, P. (Ed.) Principles of Addiction: Comprehensive Addictive Behaviors and Disorders volume 1. (pp 3-12). San Diego: Academic Press.

Wiegel, C., Sattler, S., Göritz, A. S., \& Diewald, M. (2015). Work-related stress and cognitive enhancement among university teachers. Anxiety, Stress, \& Coping, 29(1), 1-18.

Wilbert, J. 1979. Magico-Religious Use of Tobacco among South American Indians. In D. L. Browman Ed. Spirits, Shamans, and Stars. Perspectives from South America. (pp. 13-38). The Hague: Mouston.

Withington, P. (2014). Introduction: Cultures of Intoxication. Past and Present, 222 (suppl 9), 9-33. doi:10.1093/pastj/gtt027

Withington, P., \& McShane, A., Eds. (2014) Cultures of Intoxication. Special issue of Past and Present 222 (suppl 9).

Wolffgramm, J., \& A. Heyne (1991). Social Behavior, Dominance, and Social Deprivation of Rats Determine Drug Choice. Pharmacology Biochemistry and Behavior, 38, 389-399.

Xigeng, Z., L. Yonghui, L. Xiaojing, X. Lin, W. Dongmei, L. Jie, \& S. Nan. (2004). Social Crowding Sensitizes High-Responding Rats to Psychomotor-Stimulant Effects of Morphine. Pharmacology Biochemistry and Behavior, 79, 213-218.

Zapata, L., L. Pen ̃-Chocarro, G. Pe'rez-Jorda', \& Stika, H. P. (2004). Early Neolithic Agriculture in the Iberian Peninsula. Journal of World Prehistory, 18, 283-325. 


\section{University Library}

\section{- M M I N E R VA A gateway to Melbourne's research publications}

Minerva Access is the Institutional Repository of The University of Melbourne

Author/s:

Wadley, G

Title:

How psychoactive drugs shape human culture: A multi-disciplinary perspective

Date:

2016-09-01

Citation:

Wadley, G. (2016). How psychoactive drugs shape human culture: A multi-disciplinary perspective. BRAIN RESEARCH BULLETIN, 126 (Pt 1), pp.138-151. https://doi.org/10.1016/ j.brainresbull.2016.04.008.

Persistent Link:

http://hdl.handle.net/11343/274701 